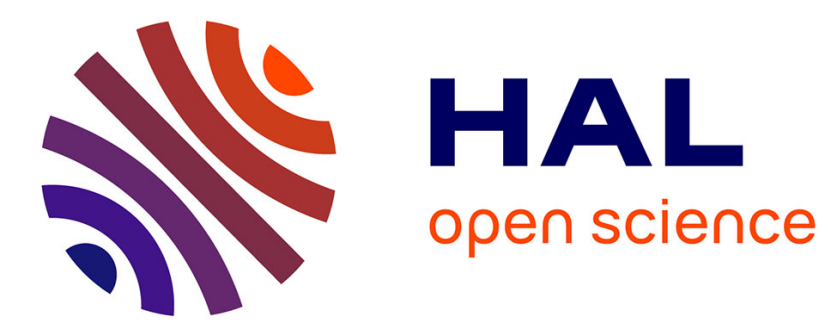

\title{
Juvenile salmonid populations in a temperate river system track synoptic trends in climate
}

\author{
Esther Clews, Isabelle Durance, Ian Vaughan, Steve Ormerod
}

\section{To cite this version:}

Esther Clews, Isabelle Durance, Ian Vaughan, Steve Ormerod. Juvenile salmonid populations in a temperate river system track synoptic trends in climate. Global Change Biology, 2010, 16 (12), pp.3271. 10.1111/j.1365-2486.2010.02211.x . hal-00552616

\section{HAL Id: hal-00552616 https://hal.science/hal-00552616}

Submitted on 6 Jan 2011

HAL is a multi-disciplinary open access archive for the deposit and dissemination of scientific research documents, whether they are published or not. The documents may come from teaching and research institutions in France or abroad, or from public or private research centers.
L'archive ouverte pluridisciplinaire HAL, est destinée au dépôt et à la diffusion de documents scientifiques de niveau recherche, publiés ou non, émanant des établissements d'enseignement et de recherche français ou étrangers, des laboratoires publics ou privés. 


\section{Global Change Biology}

rand

\section{Juvenile salmonid populations in a temperate river system track synoptic trends in climate}

\begin{tabular}{|c|c|}
\hline Journal: & Global Change Biology \\
\hline Manuscript ID: & GCB-09-0822.R1 \\
\hline Wiley - Manuscript type: & Primary Research Articles \\
\hline $\begin{array}{r}\text { Date Submitted by the } \\
\text { Author: }\end{array}$ & $10-F e b-2010$ \\
\hline Complete List of Authors: & $\begin{array}{l}\text { Clews, Esther; Cardiff University, School of Biosciences; National } \\
\text { Univerity of Singapore, Biological Sciences } \\
\text { Durance, Isabelle; Cardiff University, School of Biosciences } \\
\text { Vaughan, Ian; Cardiff University, School of Biosciences } \\
\text { Ormerod, Steve; Cardiff University, School of Biosciences }\end{array}$ \\
\hline Keywords: & $\begin{array}{l}\text { Climate , discharge, long-term study, river, salmon, stream, } \\
\text { temperature, trout. }\end{array}$ \\
\hline Abstract: & $\begin{array}{l}\text { Widespread decline among Atlantic salmon (Salmo salar) and } \\
\text { brown trout (Salmo trutta) over recent decades have been linked to } \\
\text { pollution, exploitation and catchment modification, but climate } \\
\text { change is increasingly implicated. We used long-term, } \\
\text { geographically extensive data from the Welsh River Wye, formerly a } \\
\text { major salmon river, to examine whether climatically-mediated } \\
\text { effects on juveniles ( }>0+\text { ) might contribute to population change. } \\
\text { Populations of Atlantic salmon and brown trout fell across the Wye } \\
\text { catchment respectively by } 50 \% \text { and } 67 \% \text { between } 1985 \text { and } 2004 \text {, } \\
\text { but could not be explained by pollution because water quality } \\
\text { improved during this time. } \\
\text { Stream temperatures, estimated from calibrations against weekly } \\
\text { air temperature at } 8 \text { sites, increased by } 0.5-0.7{ }^{\circ} \mathrm{C} \text { in summer and } \\
0.7-1.0{ }^{\circ} \mathrm{C} \text { in winter, with larger tributaries warming more than } \\
\text { shaded headwaters. Rates of winter warming were slightly greater } \\
\text { after accounting for the effect of the North Atlantic Oscillation ( } 1.1- \\
1.4{ }^{\circ} \mathrm{C} \text { ). However, warming through time was smaller than } \\
\text { measured variations among tributaries, and alone was insufficient } \\
\text { to explain variations in salmonid density. Instead, population } \\
\text { variations were best explained in multi-level mixed models by a } \\
\text { synoptic variate representing a trend towards hotter, drier } \\
\text { summers, implying interactions between climate warming, varying } \\
\text { discharge and fluctuatations in both brown trout and salmon. }\end{array}$ \\
\hline
\end{tabular}


Page 1 of 45

Global Change Biology

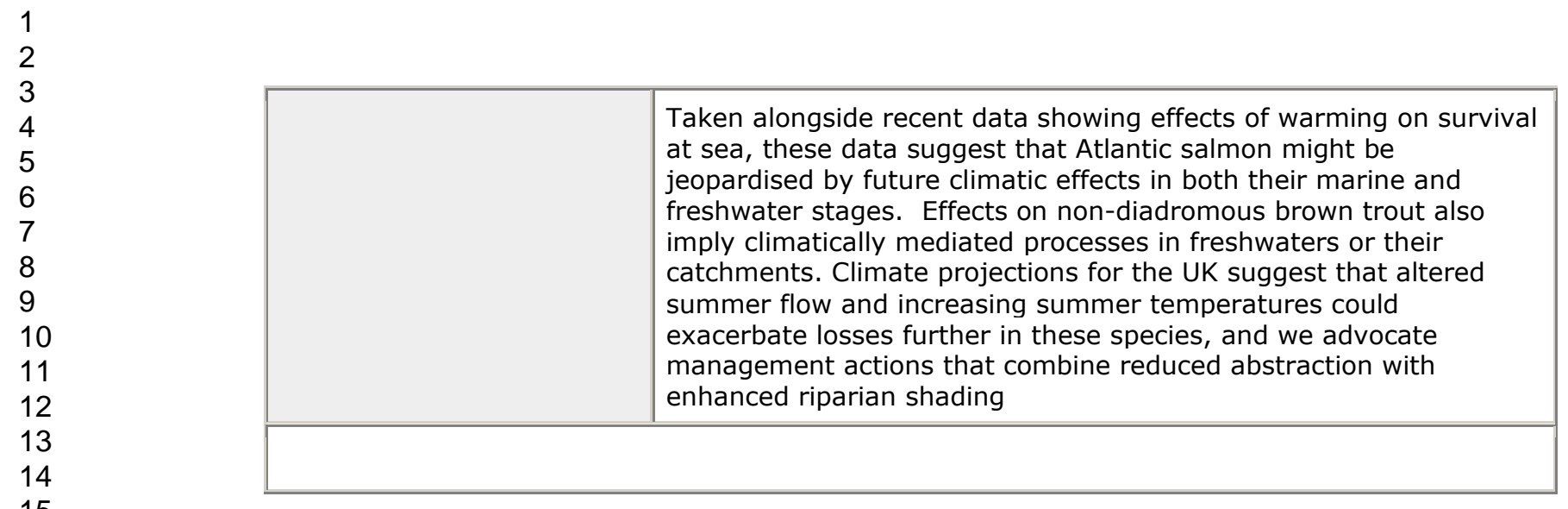

15

16

17

18

19

20

21

22

23

24

25

26

27

28

29

30

31

32

33

34

35

36

37

38

39

40

41

42

43

44

45

46

47

48

49

50

51

52

53

54

55

56

57

58

59

60 


\title{
1 Juvenile salmonid populations in a temperate river system
} $\underline{2}$ track synoptic trends in climate

\author{
ESTHER CLEWS, ISABELLE DURANCE, I. P. VAUGHAN AND S. J. ORMEROD ${ }^{\dagger *}$ \\ ${ }^{\dagger}$ Catchment Research Group, Cardiff School of Biosciences, Cardiff University, Cardiff \\ CF10 3AX, UK
}

$\underline{8}$ Correspondence: Ormerod@ cardiff.ac.uk

Running head: Climate and salmonids

\section{Abstract}

14 Widespread decline among Atlantic salmon (Salmo salar) and brown trout (Salmo trutta) 15 over recent decades have been linked to pollution, exploitation and catchment 16 modification, but climate change is increasingly implicated. We used long-term, 17 geographically extensive data from the Welsh River Wye, formerly a major salmon river, 18 to examine whether climatically-mediated effects on juveniles $(>0+)$ might contribute to 19 population change.

20 Populations of Atlantic salmon and brown trout fell across the Wye catchment 21 respectively by $50 \%$ and $67 \%$ between 1985 and 2004, but could not be explained by 22 pollution because water quality improved during this time.

$\underline{23}$ Stream temperatures, estimated from calibrations against weekly air temperature at 8 24 sites, increased by $0.5-0.7^{\circ} \mathrm{C}$ in summer and $0.7-1.0{ }^{\circ} \mathrm{C}$ in winter, with larger tributaries 25 warming more than shaded headwaters. Rates of winter warming were slightly greater $\underline{26}$ after accounting for the effect of the North Atlantic Oscillation (1.1-1.4 $\left.{ }^{\circ} \mathrm{C}\right)$. However, 27 warming through time was smaller than measured variations among tributaries, and alone $\underline{28}$ was insufficient to explain variations in salmonid density. Instead, population variations 29 were best explained in multi-level mixed models by a synoptic variate representing a $\underline{30}$ trend towards hotter, drier summers, implying interactions between climate warming, $\underline{31}$ varying discharge and fluctuations in both brown trout and salmon.

32 Taken alongside recent data showing effects of warming on survival at sea, these data $\underline{33}$ suggest that Atlantic salmon might be jeopardised by future climatic effects in both their 
Global Change Biology GCB-09-0020 revised

34 marine and freshwater stages. Effects on non-diadromous brown trout also imply 35 climatically mediated processes in freshwaters or their catchments. Climate projections $\underline{36}$ for the UK suggest that altered summer flow and increasing summer temperatures could 37 exacerbate losses further in these species, and we advocate management actions that $\underline{38}$ combine reduced abstraction with enhanced riparian shading.

$\underline{39}$

$\underline{40}$ Keywords: Climate, discharge, long-term study, river, salmon, stream, temperature, trout. $\underline{41}$ 


\section{Global Change Biology GCB-09-0020 revised}

\section{Introduction}

43 Populations of Atlantic salmon (Salmo salar) and trout (Salmo trutta) have declined in

44 recent decades across large parts of their range (Slaney et al., 1996; Parrish et al., 1998;

45 Beamish et al., 1999; Environment Agency 2003a). However, the factors involved remain

46 poorly understood despite large research efforts (Marschall and Crowder, 1996; Slaney et

47 al., 1996; Armstrong et al., 2003; Milner et al., 2003; Ormerod, 2003). Particular

$\underline{48}$ difficulties arise in migratory salmonids because life cycles in many species are divided

49 between marine and freshwater environments, where different effects operate. In

50 addition, abundance reflects both density-independent processes, such as habitat loss or

51 pollution, and also density-dependent feedbacks, such as territorial competition (Milner et

52 al., 2003; Zabel et al., 2006).

53 Key population factors almost certainly act in combination (Marschall and Crowder,

54 1996; Parrish et al., 1998; Milner et al., 2003), with density-dependence, environmental

$\underline{55}$ or demographic stochasticity, and land or river management all implicated in current

56 declining trends in salmonid populations (Wilzbach et al., 1998; Parrish et al., 1998;

57 Ormerod, 2003; Zabel et al., 2006). Effects might also be scale-dependent. At river reach

58 scales, habitat quality influences the abundance of salmonids by direct provision of

59 refugia and food resources, so that riparian or in-stream degradation can affect local

60 carrying capacity (Borsuk, et al., 2006). More widely, across river catchments, barriers

$\underline{61}$ to migration, habitat fragmentation, diffuse pollutants, agricultural intensification and

$\underline{62}$ industrialization have all had negative effects (Parrish et al., 1998; Ormerod, 2003; Suttle

63 et al., 2004; Dudgeon et al., 2006). Finally, over regional scales, direct exploitation and

64 disease can alter salmonid populations (Bowker et al., 1998; Hari et al., 2006; Quinn et 
Global Change Biology GCB-09-0020 revised

65 al., 2006). Commercial fishing of Atlantic salmon has occurred extensively across near-

66 shore areas of Europe, including Ireland and the UK, and mortality from fishing has

67 previously been implicated in decline (Common Fisheries Policy, Council Regulation

68 2371/2002/EC; Potter, et al., 2003). Evidence from angling catches suggests that

69 salmonid populations in rivers have not always recovered followed the reduction and

70 closure of commercial net fisheries in the UK over the last two decades, although this is

$\underline{71}$ likely confounded by declining angler participation (Aprahamian et al. 2009).

72 Speculation is now growing that the reduction of salmonid populations across regions

73 must involve even broader-scale pressures than those outlined above, and climatic

74 variations are implicated increasingly. Climate affects salmonids through precipitation

$\underline{75}$ and water temperature, with consequences for growth, development, behaviour and

76 survival both in freshwater and marine stages (e.g. Flebbe et al., 2006; Seo et al., 2006;

77 Walsh and Kilsby 2007; Taylor 2008). In addition, reductions in flow can reduce the

$\underline{78}$ accessibility of habitats and affect species' survival and distributions (Armstrong et al.,

79 2003; Hakala and Hartman, 2004; Riley, et al,. 2009). Similarly, increased stream

$\underline{80}$ temperatures may restrict the availability of thermal refugia in these typically cool-water

$\underline{81}$ fishes (Eaton et al. 1995; Breau, et al., 2007). At sea, rising sea-surface temperature is a

82 factor in population change (Beamish et al., 1999; Beaugrand and Reid, 2003; Tolimieri

$\underline{83}$ and Levin, 2004; Todd et al. 2008). While much attention has focused on directional

84 climate change the North Atlantic Oscillation (NAO) is also linked to changes in fish

85 production and ecology in both marine and freshwater ecosystems (Elliott et al. 2000;

86 Bradley and Ormerod, 2001; Parsons and Lear, 2001). Inter-annual variations in climate 
Global Change Biology GCB-09-0020 revised

87 - for example through drought - can also have large effects on salmonids (Elliott et al.

$\underline{88} \quad 1997)$

$\underline{89}$

90 Although long-term data sets are increasingly available through which explanations for

91 variations among salmonids might be assessed, long-term evaluations of climatic effects

92 through time or between years are still few (Thomas, 1996; Bjornstad and Grenfell, 2001;

93 Daufresne et al., 2004; Hulme, 2005; Crozier and Zabel, 2006). This is particularly the

94 case where species with and without marine phases in their life cycle, such as Atlantic

95 salmon and brown trout, have been compared in the same catchment. The River Wye, in

96 Wales, western Britain, provides a particularly important case study that allows an

97 evaluation of trends in both these species. Here, brown trout are non-anadromous, unlike

98 some other UK rivers where this species has sea-run components, thus enabling a contrast

99 with migratory salmon (Edwards and Brooker, 1982). The Wye was traditionally one of

100 the best salmon angling rivers in the UK, so that long-term and wide scale data on

101 juvenile populations are available (Gee, Milner and Hemworth 1978a,b). However, in

102 recent decades, there have been marked declines in stocks of Atlantic salmon and brown

103 trout (Gee and Milner, 1980; Gough et al., 1992; Environment Agency, 2003 a and b).

104 Because riparian and in-stream management to benefit salmonids has been attempted, and

105 some aspects of water quality have improved, there are few local, catchment-scale factors

106 that might explain this decline (Clews and Ormerod 2009; Clews, Vaughan \& Ormerod

107 2010).

$\underline{108}$ 


\section{Global Change Biology GCB-09-0020 revised}

109 Here, we identify large-scale environmental correlates with trends and fluctuations in the 110 density of Atlantic salmon and brown trout across the Wye system over a 20-year period

111 from 1984. Specifically, we test the hypotheses that i) densities of juvenile brown trout 112 and Atlantic salmon have declined across the Wye catchment and ii) trends are better 113 explained by climatic factors, rather than local water quality and iii) migratory Atlantic 114 salmon are equally tied to climatic effects as are brown trout, which might be expected if 115 climatic effects on freshwaters are important in salmonid trends.

\section{Study Area}

119 The River Wye, in temperate western Britain, rises at $677 \mathrm{~m}$ OD $\left(52^{\circ} 28^{\prime} \mathrm{N}, 3^{\circ} 45^{\prime} \mathrm{W}\right)$

120 before flowing south eastwards to join the Severn Estuary (Figure 1). Typical of upland, 121 high-velocity rivers in the UK, the Wye dominantly drains a mix of rough grazing, 122 pastoral agriculture, and deciduous woodland or forest plantation, while arable farming 123 predominates in the lower Wye valley (Edwards and Brooker, 1982). The general 124 ecology, land use and water quality have been described extensively (Edwards and 125 Brooker, 1982; Ormerod and Edwards, 1987; Jarvie et al. 2003; Clews and Ormerod, 126 2009). The temperate climate means that precipitation averages around $912 \mathrm{~mm}$ per 127 annum across the catchment, although the precipitation volumes increase towards the 128 north and west (Hughes and Morley, 2000) to 2500mm per annum (Jarvie et al., 2003; 129 NERC, 2005). Typical annual mean temperatures range from $8-11^{\circ} \mathrm{C}$, and the highest 130 monthly means reach c $19^{\circ} \mathrm{C}$. 
Global Change Biology GCB-09-0020 revised

132 Partly because of its importance for Atlantic salmon the Wye river system is both a Site

133 of Special Scientific Interest (SSSI) and Special Area of Conservation (SAC) under the

134 EU Habitats Directive (Directive 92/43/EEC) (Joint Nature Conservancy Committee, 135 2004).

136 Materials and Methods

137 Overall study design

138 Trends in salmonid populations between 1985 and 2004 were assessed from 41 of the

139 Wye's tributaries, while hydrochemical and climatic correlates with fish density were

140 appraised on 27 tributaries from which chemical data were available. Fish population data

141 were used to investigate trends in salmonid populations through time and also to whether

142 trends were catchment-wide.

$\underline{143}$

\section{Salmonid data}

145 Juvenile salmonid data were derived by electrofishing by the Environment Agency,

146 Wales (Environment Agency and CEFAS, 2004) during summer (April to October) most

147 frequently in August (61\% of samples). Since post young-of-the-year $(>0+)$ survival,

148 unlike young-of-the-year (0+) survival, is relatively constant over the months of May to

149 September we combined all available data into an annual mean for each stream reach

150 (Juanes et al. 2000). Quantitative electrofishing surveys (29\% of samples) involved three

151 electrofishing runs per reach (approx. 50m) of river to yield a population estimate as

152 density of fish per $\mathrm{m}^{2}$ of river based on catch-depletion. Semi-quantitative surveys $(71 \%$

153 of samples) involved just one run per site. Equations used to estimate equivalent

154 quantitative survey counts from semi-quantitative were established by regressing the third 
Global Change Biology GCB-09-0020 revised

155 fishing pass (Q) against the first fishing pass count (SQ) according to the methods

156 outlined by Strange et al. (1989), by which the quantitative density of juvenile salmon =

$\underline{157} 2.13+1.41$ Semi-quantitative density \pm 0.065 error $(\mathrm{R}-\mathrm{Sq}=82.5 \% 5.4$ standard error $)$

158 while the quantitative density of juvenile trout $=0.703+1.35$ Semi-quantitative density \pm

1590.048 error $(\mathrm{R}-\mathrm{Sq}=88.6 \%)$.

160 The majority of rivers were electrofished once each year, but some were sampled more

161 than once or had multiple sample sites. In these cases, a mean annual density was

162 calculated for each reach (see Appendix 1 for the frequency of sampling within each

163 river). Densities were log transformed to achieve normality and homogenise variances.

$\underline{164}$

165 Electrofishing sites were matched to water chemistry samples based on their proximity,

166 geology and stream order. Electrofishing reaches without comparable water chemistry

167 data $(n=14)$ were excluded from any analysis of fisheries trends against chemical and 168 climatic variables.

$\underline{169}$

$170 \quad$ Water chemistry

171 Data on chemical quality, analysed by standard methods, were obtained from the 172 Environment Agency Water Management Information System (WMIS) database (SCA, 173 1978, 1979, 1981, 1988). Ammoniacal nitrogen (mg/l), dissolved oxygen (mg/l), 174 Biological Oxygen Demand (BOD [ATU]) (mg/l) and $\mathrm{pH}$ were monitored monthly 175 throughout all years of the study except for 1993. The total concentration of ammonium 176 salts $(\mathrm{NH} 4+)$ and free ammonia (NH3) was determined form the reaction of ammonia 


\section{Global Change Biology GCB-09-0020 revised}

177 with hypochlorite to form monochloramine and measured colorimetrically at $656 \mathrm{~nm}$ as a

178 blue indo-phenol complex using a Discrete Analyser - Aqua 800/Konelab 30

179 (SCA, 1981). Dissolved oxygen concentration was measured by the Winkler manual

180 titration method (SCA, 1979). The Biochemical Oxygen Demand (BOD) measured the

181 uptake of dissolved oxygen by a sample during 5 days at $20^{\circ} \mathrm{C}$ in the dark and was

182 analysed via a SKALAR automated system in the presence of allylthiourea (ATU) to

183 suppress the uptake of oxygen by ammonia (SCA, 1988). $\mathrm{pH}$ was measured

184 electrometrically with a glass electrode WTW530 pH meter (SCA, 1978).

$\underline{185}$

186 Chemical samples were defined as either 'summer' (April - September) and 'winter'

187 (October - March), and mean calculated for the seasons antecedent to electrofishing.

188 Missing values were replaced, where possible, with the mean for the appropriate year, 189 season and river reach.

$\underline{190}$

191 Climatic variables

192 Climatic data came from several sources. To assess climatic trends across the catchment 193 as a whole, mean monthly minimum (tmin), maximum (tmax) air temperatures $\left({ }^{\circ} \mathrm{C}\right)$, and 194 rainfall (mm), were obtained from Ross-on-Wye (National Grid Reference (NGR) SO $\left.195597238 ; 51^{\circ} 54^{\prime} 40.55^{\prime \prime} \mathrm{N} 2^{\circ} 35^{\prime} 8.92^{\prime \prime}\right)$, the meteorological station at which the most 196 complete daily records were available (Met Office, 2004). We supplemented these with 197 additional temperature records available from daily (1988-2004) or weekly (1982) data 198 from Llysdinam Field Centre, Newbridge-on-Wye (NGR SO 009 586; 53 12' 59" N $1993^{\circ} 27^{\prime} 3^{\prime \prime} \mathrm{W}$ ), directly adjacent to the river temperature sites (see below). Fewer data were 


\section{Global Change Biology GCB-09-0020 revised}

$\underline{200}$ available from stream or river temperatures, but extensive studies indicate that these can

201 be modelled as a reasonable approximation using air temperature: while local factors

202 such as groundwater inputs, evaporative cooling, shading and discharge affect the exact

203 nature of their inter-relationship, mean air and stream temperatures are closely correlated

204 over weekly to monthly time steps because both air and water are warmed by similar

205 processes (Webb, Clack and Walling 2003; Caissie 2006; Durance and Ormerod 2009).

206 As an example, between 1980 and 2003, monthly mean temperatures at Ross-on-Wye

207 explained $98 \%$ of the variation in mean monthly stream-water temperatures available

$\underline{208}$ from the directly adjacent headwaters of the Afon Tywi with a regression slope of 0.81

209 (d.f.=294, F = 13,121, P<0.001 $\mathrm{r}^{2}=0.97$; Durance and Ormerod 2007). This illustrated

$\underline{210}$ that local stream temperatures tracked air temperature, but with increasing damping at

211 higher values. Calibrations between river temperature and air temperature at Llysdinam

212 available over a one-year period in 1982 at eight adjacent sites illustrated how this

$\underline{213}$ damping effect varied between stream types, with unshaded higher-order tributaries of

214 the Wye tracking air temperature more directly than shaded low-order streams (Table 1;

215 Ormerod 1985; SO010512; SO014583; SN999569; SO033516; SN997530; SO019573;

216 SO032541; SO044487; altitudes 120-200m above sea level). We used these local

217 calibrations to estimate from the air-temperature series how stream temperature in

$\underline{218}$ contrasting locations has varied through time. Temperatures for each salmonid sampling

219 location were further adjusted for altitude according to the environmental lapse rate of 6.5

$\underline{220}{ }^{\circ} \mathrm{C}$ per $1000 \mathrm{~m}$. 


\section{Global Change Biology GCB-09-0020 revised}

222 Median winter (October -March) and summer (April - September) discharge $\left(\mathrm{m}^{3} / \mathrm{s}\right)$ data

223 were taken from the Gwy and Hafren Flumes, operated by the Centre for Ecology and

224 Hydrology on Plynlimon, where the Wye rises $\left(52^{\circ} 27: 26^{\prime} \mathrm{N}, 3^{\circ}: 47: 46^{\prime} \mathrm{W}\right)$. Our

225 assumption was that inter-annual trends in relative discharge here represented wider

226 regional pattern across the Wye even though the total discharge-varied between sites. We

227 validated this assumption by comparison with discharge at a gauged site on the Afon

228 Cothi, c $50 \mathrm{~km}$ to the west in the adjacent Tywi catchment $\left(51^{\circ} 51: 37^{\prime} \mathrm{N}, 4^{\circ} 11: 00^{\prime} \mathrm{W}\right)$,

229 where discharge correlated highly significantly with the upper Wye $(\mathrm{r}=0.89, \mathrm{n}=289$

230 monthly mean values, $\mathrm{P}<0.0001)$. Examination of other parameters to describe

231 discharge based on the flow-duration curve (e.g. 5\% and $95 \%$ flow percentiles) gave

232 results that were highly inter-correlated with median discharge and equally inter-

$\underline{233}$ correlated with variates describing inter-annual climate variability.

$\underline{234}$

235 Because of expectations from patterns elsewhere in Wales (Durance and Ormerod 2007),

236 we investigated whether the North Atlantic Oscillation (NAO) contributed to inter-annual

237 variation in climate and temperature using the mean difference between the normalised

238 sea level pressure over Gibraltar and the normalised sea level pressure over Southwest

239 Iceland. The NAO index is associated with changes in the surface westerlies across the

240 North Atlantic to Europe and represents dry, cold winters when negative and warm wet

241 winters when positive (Hurrell, 1995). Monthly NOA index values between 1984 and

242 2004 were obtained from the Climatic Research Unit and used to calculate summer and

243 winter means for use in the principal components analyses described below (Climatic

244 Research Unit, 2005; Osborn, 2005). 
Global Change Biology GCB-09-0020 revised

246 Data analysis

247 To establish whether salmonid populations declined through time, the effect of year on $\underline{248}$ their respective density was established from multi-level linear regression (also called 249 mixed effects models) using the lme function in R 2.9 (R Development Core Team 2009). 250 Multilevel models are increasingly adopted over repeated measures ANOVA and time251 series analyses in longitudinal studies (Van Der Leeden,1998; Pinheiro and Bates 2000, 252 Twisk, 2006). Models account for the dependency of observations by recognising a 253 hierarchical structure in the data whereby observations are nested within rivers in this 254 instance. This enables analysis of continuous and relatively short time series data, such as 255 our 19 year salmonid population data. We used a two-level design, whereby observations 256 were clustered within rivers in a 'random intercept' model that accounted for the 257 autocorrelated nature of the repeated observations within rivers (Twisk, 2006). A random $\underline{258}$ intercept regression model that included a random slope improved the (log likelihood) fit 259 of the model (Twisk, 2006). The correlation between the random intercept and random 260 slope was used to indicate whether rivers with high or low densities of salmonids were 261 more or less susceptible to population decline. A negative correlation would indicate that 262 rivers with a higher density of salmonids had a low slope, or less dramatic decline 263 assuming a negative relationship between density and time.

264 Spearman's correlation coefficients $\left(r_{s}\right)$ were calculated between water quality, climate 265 and year. We then used Principal Components Analysis (PCA) separately on the 266 correlation matrices of climatic and water quality variables, respectively for summer and 267 winter, to derive variates describing trends in environmental variation through time. 


\section{Global Change Biology GCB-09-0020 revised}

268 To assess which synoptic environmental variates from PCA best explained trends in the

$\underline{269}$ density of juvenile salmonid populations through time, we again used multi-level linear

270 regression. A two-level design, similar to that described for the assessment of the effects

271 of time on density, was adopted whereby observations were clustered within rivers in a

272 'random intercept' model that accounted for the autocorrelated nature of the repeated

273 observations within rivers (Twisk, 2006). The fixed effects of each of the climatic

274 variables on salmonids density were therefore established after using random coefficients

275 for each river to model the covariance structure of the data. The inclusion of a random

276 slope into the random intercept regression model did not significantly improve fits.

277 However, there was strong evidence to support the inclusion of a first-order

$\underline{278}$ autoregressive (AR1) term to model residual autocorrelation within rivers $(\triangle \mathrm{AIC}=8.0$

$\underline{279}$ and 39.5 for salmon and trout respectively). The predicted change in density with each

280 climatic variable was estimated by examining raw variables values at the 5, 25, 75 and 95

281 percentiles of PCA scores.

282 All data were transformed to reduce skew and kurtosis when appropriate. Analyses were

$\underline{283}$ repeated for juvenile salmon $(>0+)$ and juvenile trout $(>0+)$ and Bonferroni adjustment

$\underline{284}$ for multiple tests are reported (Quinn and Keough, 2002).

$\underline{285}$

$\underline{286}$ Results

$\underline{287}$

$\underline{288}$ Trends in salmonid density

289 Juvenile salmon and trout densities declined between 1985 and 2004 across the Wye

290 catchment by $50 \%$ and $67 \%$, respectively (Figure 2, Table 2). This change was 


\section{Global Change Biology GCB-09-0020 revised}

291 significant, as demonstrated by a negative regression coefficient for density of both 292 salmon and trout juvenile with year (Table 2). The correlation between the random 293 intercept and random slope was negative (salmon: -0.26 , Wald $Z=2.48 ; \rho=0.013$; trout: 2940.28 , Wald $\mathrm{Z}=2.16 ; \rho=0.031$ ) indicating that rivers with higher densities of salmonids 295 had a low slope, or less dramatic decline in populations. In addition to declining trends 296 through time, populations were characterised by marked inter-annual variations (Figure 297 2).

$\underline{298}$

299 Long-term environmental change

300 From the early 1980s, water quality generally improved across the Wye catchment, seen 301 for example in declining biochemical oxygen demand ('summer': $\mathrm{r}_{\mathrm{s}}=-0.59 \mathrm{P}<0.05$; 302 'winter' $\mathrm{r}_{\mathrm{s}}=-0.59 \mathrm{P}<0.05$ ) and ammonia ('summer': $\mathrm{r}_{\mathrm{s}}=-0.73 \mathrm{P}<0.01$; 'winter': $\mathrm{r}_{\mathrm{s}}=-$ $3030.39 \mathrm{P}<0.05)$. Average concentrations of oxygen were seldom below $95 \%$ saturation, or 304 below 9-10 mg/L, and did not decrease significantly through time despite increasing 305 temperature (see below). These chemical variations were well captured by single 306 principal components in either winter or summer (Table 3).

$\underline{307}$

308 Mean air temperatures over the study area increased during the last 25 years by c $1.3{ }^{\circ} \mathrm{C}$ 309 (from 8.5 to $9.8^{\circ} \mathrm{C}$ ), and local calibrations suggested that this would have increased river $\underline{310}$ temperatures (Table 1; Figure 3). Thus, over the 19 years covered by data on salmonid 311 density, headwaters were estimated to have warmed in summer, annually and in winter by $\underline{312} 0.5,0.6$ and $0.7^{\circ} \mathrm{C}$, respectively, while larger tributaries warmed by $0.6,0.8$ and $1.0{ }^{\circ} \mathrm{C}$. 313 Estimated winter temperatures were strongly affected by the NAO in both headwaters 


\section{Global Change Biology GCB-09-0020 revised}

314 (annual mean winter temperature $=5.93 \pm 0.15{ }^{\circ} \mathrm{C}+0.212 \pm 0.065 \times \mathrm{NAO}$ ) and larger

$\underline{315}$ tributaries (mean winter temperature $=6.40 \pm 0.19^{\circ} \mathrm{C}+0.279 \pm 0.086 \times \mathrm{NAO}$ ), with both

$\underline{316}$ relationships highly significant $\left(\mathrm{F}_{1,24}=10.40, \mathrm{r}^{2}=0.27, \mathrm{P}<0.01\right)$. After accounting for

$\underline{317}$ this effect, winter warming over the 19 years of the salmonid study was 1.1 and $1.4{ }^{\circ} \mathrm{C}$ in

$\underline{318}$ headwaters and larger tributaries, respectively (Figure 3).

$\underline{319}$

320 In contrast to temperature, discharge in the Wye has not changed directionally through

321 time over the period studied, but low and high flow periods have been apparent (Figure

322 4). Nor have rainfall or insolation (as daily hours sun) changed through time (both rs <

$3230.3, \mathrm{P}>0.1)$. Inter-annual variations in all these climatic variables were well described in

324 PCA by single variates. Among summers, positive scores in this component reflected

325 low discharge, high maximum temperatures and sunshine while negative values reflected

326 increased rainfall and discharge when negative (Table 3). In winter, climatic variations

$\underline{327}$ mostly reflected warmer temperatures, higher rainfall, greater discharge and a stronger

328 contribution from the NAO than in summer (Table 3).

$\underline{329}$

$\underline{330}$ Environmental correlates with salmonid density

$\underline{331}$

332 Individual Spearman's correlations showed that brown trout populations declined $\underline{333}$ significantly with increasing maximum temperature $\left(r_{s}=-0.25, P=0.02\right)$ and discharge $\left(r_{s}\right.$ $\underline{334}=0.12 \mathrm{P}=0.02)$, while salmon densities declined with increasing solar radiation $\left(\mathrm{r}_{\mathrm{s}}=-0.17\right.$ 335 $\mathrm{P}=0.002)$ and maximum temperature $\left(\mathrm{r}_{\mathrm{s}}=-0.126 \mathrm{P}=0.018\right)$. However, these individual 336 relationships were weak, and multilevel regression produced stronger relationships with 


\section{Global Change Biology GCB-09-0020 revised}

337 the synoptic climate variates in both species, particularly when lagged against the $\underline{338}$ previous summer (Table 4). Densities of both Atlantic salmon and brown trout declined 339 with increasing scores on the index of antecedent summer climate (i.e. climate PC1), $\underline{340}$ indicating that reductions in density were greatest following hotter, sunnier and drier 341 conditions (Table 4; Figure 5). On average, a shift across the inter-quartile range for this

342 variate equated to a $0.3^{\circ} \mathrm{C}$ increase in maximum temperature and a $10.1 \mathrm{~mm}$ decrease in $\underline{343}$ monthly rainfall. This, in turn, appeared to reduce salmon densities by 1.7 salmon per 344 $100 \mathrm{~m}^{2}$ of river and 1.8 trout (per $100 \mathrm{~m}^{2}$ of river) respectively (Table 5), or around 17345 $20 \%$ of typical mean densities at the beginning of the study. Neither winter climate nor $\underline{346}$ variates describing water quality explained significant variations in salmonid density.

\section{$\underline{348}$ Discussion}

349 These data, collected over a 20-year period from two salmonids with contrasting life$\underline{350}$ cycles, support all three of our hypotheses: both species have declined substantially and 351 unequivocally across the Wye catchment, with trends and fluctuations better explained by 352 climatic factors than any other variable examined. Of considerable importance, changes $\underline{353}$ in both migratory Atlantic salmon and non-migratory brown trout populations appeared 354 to be linked to synoptic climatic effects, with both species' populations declining when $\underline{355}$ increasing summer temperature was combined with reduced discharge. While factors at 356 other scales might affect salmon population and demographics, such as at-sea survival or 357 exploitation through commercial fishing (e.g. Gee and Milner, 1980; Finney et al., 2000; 358 McFarlane et al., 2000; Quinn et al., 2006; Ruggerone et al., 2007), within-catchment 359 processes affecting recruitment or survival must also be important (Rieman et al., 2001; 


\section{Global Change Biology GCB-09-0020 revised}

360 Regetz, 2003). Local water-quality effects in the Wye system include pollutants such as

361 pyrethroids (Moore and Waring, 2001), episodic acidification in the upper catchment

362 (Lewis et al. 2007) and eutrophication in the lower catchment (Clews and Ormerod

363 2009), but these effects have all abated through time and so cannot explain population

364 reduction (Ormerod and Durance 2009). Notwithstanding the important caveat that our

365 analysis is based on correlation, climatic effects are the most plausible explanation for the

366 trends and fluctuations observed, as well as the best statistical explanation. A reduction

$\underline{367}$ in commercial net fisheries in UK and Ireland over the study period also supports this

$\underline{368}$ assertion. We note here that, although effects on both brown trout and salmon in our

369 analysis were apparently captured by the same broad climatic variables, the exact

$\underline{370}$ processes involved could differ between these two species, not least because of their

371 different habitat requirements within stream systems (Armstrong et al., 2003).

$\underline{372}$

$\underline{373}$ One important factor to consider in assessing long-term population data under varying

374 climatic conditions is that temperature can affect the efficiency of electrofishing gear.

375 Such effects could, in turn, potentially confound any putative effects of increasing

$\underline{376}$ temperature on population estimates. However, the effects of a $1^{\circ} \mathrm{C}$ temperature increase

$\underline{377}$ on capture efficiency are likely to be far smaller than the declines observed both salmon

$\underline{378}(50 \%)$ and trout juveniles $(67 \%)$ in this study: the conductivity of stream water is reduced

379 by only $2 \%$ per ${ }^{\circ} \mathrm{C}$ (Bohlin et al. 1989). Alabaster and Hartley (1962) described the

$\underline{380}$ impact of conductivity on the percentage of a fish population caught by direct current

381 electrofishing according to the regression equation $\mathrm{y}=0.27 \mathrm{x}-9.6$, where $\mathrm{y}$ is the

382 percentage catch, and $\mathrm{x}$ is the conductivity $\left(\mu \mathrm{S} \mathrm{cm}^{-1}\right)$ of the water. In 2003 , the in situ 


\section{Global Change Biology GCB-09-0020 revised}

383 conductivity was measured across streams within the Wye catchment and ranged from

384161 to $352 \mu \mathrm{S} \mathrm{cm}^{-1}$. According to Alabaster and Hartley's (1962) equation, an increase in $\underline{385}$ temperature of $1{ }^{\circ} \mathrm{C}$ would increase the percentage of the fish population caught, rather 386 than decreasing it, but by just 0.9 to $1.9 \%$ over the range of conductivities encountered in 387 the Wye. In addition to altering the stream conductivity, temperature can also affect fish $\underline{388}$ behaviour and physiology (Bohlin et al. 1989). At higher water temperatures, fish are 389 more likely to avoid sampling gear due to an increased metabolism and associated 390 capacity for movement (Hayes and Baird 1994). Conversely, behaviours such as fish

391 burrowing into the substrate at low temperatures may also prevent capture, and floatation 392 rates are greater in warmer water thus possibly offsetting the effects of the former 393 (Reynolds, 1996; Roni and Fayram 2000). These effects are currently harder to estimate 394 quantitatively than temperature effects through altered conductivity.

396 In locations elsewhere, there is strong evidence that climate is a key factor regulating 397 salmonid populations (Beamish et al., 1999; Beaugrand and Reid, 2003; Tolimieri and 398 Levin, 2004; Zabel et al., 2006; Walsh and Kilsby, 2007). Climatic effects on salmonids, 399 such as those we detected, are therefore entirely consistent with expectation from current 400 climatic trends, to which temperate, upland rivers appear highly sensitive (Durance and 401 Ormerod 2007; 2009). Climate-related variables, such as rainfall and temperature, can 402 impact directly on the habitats preferred by salmonids, influencing their behaviour, 403 growth and survival (e.g. Flebbe et al., 2006; Seo et al., 2006; Taylor 2008). Placed by 404 classical studies of river zonation into the narrow, shallow, fast flowing, clear water, 405 upstream 'trout zone' (Hawkes, 1975), the fry $(0+)$ and juveniles $(<0+)$ of $S$. salar and $S$. 
Global Change Biology GCB-09-0020 revised

406 trutta require well-oxygenated $\left(5.0-5.5 \mathrm{mg} \mathrm{l}^{-1}\right.$ ), cool (optimally $13-16{ }^{\circ} \mathrm{C}$ ), relatively fast 407 flowing water (approximately $10-30 \mathrm{~cm} \mathrm{~s}^{-1}$ and $20-50 \mathrm{~cm} \mathrm{~s}^{-1}$ respectively), and 408 inhabiting deeper water as they grow (Armstrong et al., 2003). Conditions in the Wye, 409 particularly in larger unshaded tributaries, have increasingly exceeded this temperature 410 optimum over the last 20 years (see Figure 3). As poikilotherms, the foraging behaviour 411 and habitat use of salmonids is strongly influenced by temperature (Armstrong et al., 412 2003). Elevated temperatures in temperate climates may extend the growing season for 413 salmonids while also increasing metabolic demands and food requirements while 414 possibly also increasing susceptibility to disease (Elliot et al., 1998). For example, in 415 alpine streams in Switzerland increased water temperatures induced higher incidences of 416 proliferative kidney disease in brown trout at higher altitudes (Hari et al., 2006).

418 Changes in the intensity and frequency of rainfall affect river-flow regimes and have 419 implications for the accessibility, permanence and suitability of habitats, and hence 420 salmonid distribution (Armstrong et al., 2003; Hakala and Hartman, 2004). Recent 421 experimental manipulations of flow to mimic low summer discharge in a British chalk 422 stream produced results consistent with our data from the Wye, showing how increased $\underline{423}$ mortality of both salmon and trout under low summer flow reflected reduction in habitat 424 availability (Riley, et al., 2009). Interesting in our study was that low-flow and warming 425 effects both appeared to contribute to population reduction, and again this is consistent 426 with previous observation. For example, in the Upper Rhône River, low flow and high 427 temperature favoured thermophilic fish species (e.g. Leuciscus cephalus and Barbus $\underline{428}$ barbus) at the expense of northern, cold-water fish species (e.g. Leuciscus leuciscus) 
Global Change Biology GCB-09-0020 revised

429 (Daufresne et al., 2004). One possibility that requires further investigation is that the 430 availability of thermal refuges in rivers declines at low flow in ways that prevent 431 salmonids from finding and occupying locally cooler micro-environments (Clark, Webb 432 and Ladle 1999; Arscott, Tockner and Ward 2001; Breau et al. 2007). The risk of such 433 effects is supported by evidence that i).small-scale thermal gradients increase in rivers 434 with increasing depth (as well as with lateral shade; Clark et al. (1999) and ii) increased 435 discharge and depth increase thermal mass and thermal inertia such that rivers track air 436 temperature less closely as flow increases (Webb et al. 2003). Further work is now 437 required to establish exactly where in river systems, when and how combined low flows $\underline{438}$ and elevated temperatures might be most damaging to salmonids.

$\underline{440}$ One technical component of our analytical approach is that it appears to assume linear 441 responses between salmon, trout and environmental processes affecting populations. 442 However, species do not necessarily respond linearly to environmental gradients 443 (Armstrong et al., 2003).. For example, growth rates are temperature-dependent and 444 reach an asymptotic optima at 15.9 and $13.1^{\circ} \mathrm{C}$ in salmon and trout respectively (Elliott 445 and Hurley, 1995, 1997). To assess the possibility of non-linear relationships between 446 climate and salmon or trout densities, we re-fitted models using generalised additive 447 mixed modelling using the GAMM approach of Wood (2006) Generalized Additive 448 Models, Chapman \& Hall) - i.e. employing generalised cross validation to select an 449 appropriate degree of smoothing for each variable. There was insufficient evidence that $\underline{450}$ the relationships between salmon, trout and summer climate or any measure of water 451 quality were non-linear, selecting a linear fit for the model. The linear models presented 


\section{Global Change Biology GCB-09-0020 revised}

452 here therefore provide the best current guide to the potential responses of salmonids to

453 climatic variation within their optimal range. Interestingly, there was some evidence of a

454 weak non-linear relationship between trout, salmon and winter climate, but it arose only

455 with lags of $>1-2$ winters before the time of sampling, and moreover was not statistically

456 significant after modelling residual autocorrelation. We therefore suggest that such winter

457 climatic effects in the Wye, either alone or in combination with summer effects, would

458 warrant further investigation only when a longer data run is available. Salmonid life

459 cycles operate over multiple years and are complex, involving migration to accommodate

460 the different habitat preferences of each life-stage (see Crisp, 1996; Armstrong et al.,

461 2003). For example, the life cycle of salmon in the Wye system require at least 2 years

462 from egg to adult spawner, and more in the case of multi-sea-winter fish ( $>3$ years) which

463 made up approximately 90\% of rod catches in 1977 (Edwards and Brooker, 1982).

464 Climatic effects operating on salmonids are therefore integrated across the entire lifespan

$\underline{465}$ of the fish as well as that of the previous generation. The numbers of Atlantic Salmon

466 spawners returning to the Wye have declined over the study period - notably for the

467 number and proportion of multi-sea-winter fish (Environment Agency, 2003a). At least in

468 this species (as opposed to the Wye's brown trout), the influence of climatic and

469 anthropgenic factors affecting potential spawners in the marine environment cannot be

$\underline{470}$ discounted as an influence on the decline of salmon juveniles (Kennedy and Crozier

471 1993; Potter et al., 2003; Jonsson and Jonsson, 2004). Notwithstanding these

472 possibilities, the period between emergence and the establishment of feeding territories in

473 salmonids is critical, and this is the period we were particularly interested in capturing

474 when testing hypotheses about summer climate (Armstrong et al., 2003; Nislow et al., 
Global Change Biology GCB-09-0020 revised

475 2004). Climatic variables presented here operated over this critical period in the 476 development of the juvenile salmonids in the Wye. Correlations between climatic 477 variables and salmon densities were generally greater for the preceding year when 478 considered against the each of the preceding 7 years respectively. The relatively short 479 time-lags over which climate variables were found to affect salmon density significantly $\underline{480}$ imply that freshwater condition rather than marine factors affected the variations $\underline{481}$ observed in juveniles.

$\underline{482}$

$483 \quad$ Future climatic effects and their management

484 If the effects detected in the Wye are substantiated by surveys or experiments elsewhere, 485 there are clearly potential implications for the future status of salmonids under climate 486 change. This has particular importance in the case of Atlantic salmon given its position 487 on the EU Habitats Directive (92/43/EEC) and its relevance to the designation of rivers as 488 'Special Areas of Conservation as part of the 'Natura 2000' network. The UK climate is 489 likely to warm between $2-5{ }^{\circ} \mathrm{C}$ by 2080 (Hulme et al., 2002), with winters in western 490 Britain wetter but summers drier (Conway, 1998; Hulme et al., 2002). Effects of this 491 magnitude are already developing in British rivers (Durance and Ormerod 2007; 2009), 492 while studies in the Upper Wye suggest that the occurrence and amount of precipitation 493 will decrease in summer and autumn, while evapotranspiration will increase, resulting in 494 more frequent 'low flows' (Pilling and Jones, 2002). Extreme drought events, as 495 experienced in 1990, 1995, 2003 and also in 1976 with catastrophic effects on salmonids 496 (Edwards and Brooker, 1982), are likely to occur at increased frequency. Given the trends 497 recorded here, changes of this type would be detrimental to salmonid populations unless 


\section{Global Change Biology GCB-09-0020 revised}

498 adaptive management actions are taken to offset the worst effects. Maintaining river

499 discharge through reducing abstraction and increasing compensation flow will be

500 important, while the use of riparian shade to reduce the effects of adverse summer

501 temperatures is also gaining favour (Rutherford et al., 2004; Watanabe et al., 2005;

502 Ormerod 2009). Our own evidence supports this effect (Figure 3), while similar results

503 elsewhere suggests that riparian shade can reduce summer temperature at least as

504 effectively as the effect of groundwater damping on chalk-fed rivers (Table 6). On this

505 basis, riparian shading could become a critical tool in maintaining salmonids in the

506 southern part of their current European range.

$\underline{507}$

\section{$\underline{508}$ Acknowledgements}

509 We thank the Environment Agency (Wales), and particularly Peter Gough, for allowing

$\underline{510}$ access to long-term data on water quality and salmonid populations. He, Guy Mawle,

511 Graham Lightfott, Prof Bruce Webb and two anonymous reviewers provided helpful

512 comments on the manuscript. EC was funded by the Wye and Usk Foundation, and we

513 thank Dr Stephen Marsh-Smith. IPV was supported by Fellowship of the UK Research

514 Councils and ID was funded by the Natural Environment Research Council through a

$\underline{515}$ Daphne Jackson Fellowship. 
Global Change Biology GCB-09-0020 revised

$\underline{517}$

$\underline{518}$

$\underline{519}$

$\underline{520}$

$\underline{521}$

522

$\underline{523}$

524

$\underline{525}$

$\underline{526}$

$\underline{527}$

$\underline{528}$

$\underline{529}$

$\underline{530}$

$\underline{531}$

$\underline{532}$

$\underline{533}$

$\underline{534}$

$\underline{535}$

536

$\underline{537}$

$\underline{538}$

$\underline{539}$

$\underline{540}$

541

$\underline{542}$

$\underline{543}$

$\underline{544}$

$\underline{545}$

$\underline{546}$

$\underline{547}$

$\underline{548}$

$\underline{549}$

$\underline{550}$

$\underline{551}$

$\underline{552}$

$\underline{553}$

554

555

$\underline{556}$

557

$\underline{558}$

559

560

$\underline{561}$

$\underline{562}$

\section{References}

Alabaster JS, Hartley WG, (1962) The efficiency of a direct current electric fishing method in trout streams. Journal of Animal Ecology, 31, 2 385-388.

Aprahamian M W, Hickley P, Shields BA, Mawle GW (2009) Examining changes in participation in recreational fisheries in England and Wales. Fisheries Management and Ecology, in press. DOI: 10.1046/j.1365-2427.1998.00294.x

Armstrong JD, Kemp PS, Kennedy GJA, Ladle M, Milner NJ (2003) Habitat requirements of Atlantic salmon and brown trout in rivers and streams. Fisheries Research, 62, 143-170.

Arscott DB, Tockner K, Ward JV (2001) Thermal heterogeneity along a braided floodplain river (Tagliamento River, northeastern Italy). Canadian Journal of Fisheries and Aquatic Sciences, 58, 2359-2373

Beamish RJ, McFarlane GA, Thomson, RE (1999) Recent declines in the recreational catch of coho salmon (Oncorhynchus kisutch) in the Strait of Georgia are related to climate. Canadian Journal of Fisheries and Aquatic Sciences, 56, 506-515.

Beaugrand G, Reid PC (2003) Long-term changes in phytoplankton, zooplankton and salmon related to climate. Global Change Biology, 9, 801-817.

Bjornstad ON, Grenfell BT (2001) Noisy clockwork: Time series analysis of population fluctuations in animals. Science, 293, 638-643.

Bohlin T, Hamrin S, Heggberget TG, Rasmussen G, and Saltveit SJ (1989) Electrofishing - Theory and practice with special emphasis on salmonids. Hydrobiologia, 173, 9-43.

Borsuk ME, Reichert P, Peter A, Schager E, Burkhardt-Holm P (2006) Assessing the decline of brown trout (Salmo trutta) in Swiss rivers using a Bayesian probability network. Ecological Modelling, 192, 224-244.

Bowker DW, Ferns PN, Phillips DR, Mawle, GW (1998) Modelling the impact of the regulation of estuarine drift-netting on the declared rod catch of Atlantic salmon Salmo salar L. in the River Usk. Freshwater Biology, 39, 569-576.

Bradley DC, Ormerod SJ (2001) Community persistence among stream invertebrates tracks the North Atlantic Oscillation. Journal of Animal Ecology, 70, 987-996.

Breau C, Weir LK, Grant JW (2007) Individual variability in activity patterns of juvenile Atlantic salmon (Salmo salar) in Catamaran Brook, New Brunswick. Canadian Journal of Fisheries and Aquatic Sciences, 64, 486-494.

Caissie D (2006) The thermal regime of rivers: a review. Freshwater Biology, 51, 13891406.

Clark E, Webb BW, Ladle M (1999) Microthermal gradients and ecological implications in Dorset rivers. Hydrological Processes, 13, 423-438

Clews E, Ormerod SJ (2009) Improving bio-diagnostic monitoring using simple combinations of standard biotic indices. River Research and Applications, 25, 348361.

Clews E, Vaughan IP, Ormerod SJ (2010) Evaluating riparian restoration in a temperate river-system using a standardized habitat survey method. Aquatic Conservation: Marine and Freshwater Ecosystems, DOI: 10.1002/aqc.1096, in press

Climatic Research Unit (2005) North Atlantic Oscillation (NAO). nao.dat http://www.cru.uea.ac.uk/cru/data/nao.htm [Accessed:18/8/2008]. 
Global Change Biology GCB-09-0020 revised

$\underline{563}$

$\underline{564}$

$\underline{565}$

$\underline{566}$

$\underline{567}$

$\underline{568}$

$\underline{569}$

$\underline{570}$

$\underline{571}$

$\underline{572}$

$\underline{573}$

$\underline{574}$

$\underline{575}$

$\underline{576}$

$\underline{577}$

$\underline{578}$

$\underline{579}$

$\underline{580}$

$\underline{581}$

$\underline{582}$

$\underline{583}$

$\underline{584}$

$\underline{585}$

$\underline{586}$

587

$\underline{588}$

$\underline{589}$

$\underline{590}$

$\underline{591}$

$\underline{592}$

$\underline{593}$

$\underline{594}$

$\underline{595}$

$\underline{596}$

597

$\underline{598}$

$\underline{599}$

$\underline{600}$

$\underline{601}$

$\underline{602}$

$\underline{603}$

$\underline{604}$

$\underline{605}$

$\underline{606}$

$\underline{607}$

$\underline{608}$

Common Fisheries Policy. Council Regulation (EC) No 2371/2002 of 20 December 2002 on the conservation and sustainable exploitation of fisheries resources under the Common Fisheries Policy. http://eur-lex.europa.eu/LexUriServ/site/ en/oj/2002/1_358/__35820021231en00590080.pdf

Conway D (1998) Recent climate variability and future climate change scenarios for Great Britain. Progress in Physical Geography, 22, 350-374.

Crisp DT (1996) Environmental requirements of common riverine European salmonid fish species in fresh water with particular reference to physical and chemical aspects. Hydrobiologia, 323, 201-221.

Crisp DT (1997) Water temperature of Plynlimon streams. Hydrology and Earth System Sciences, 1, 535-540.

Crozier L, Zabel RW (2006) Climate impacts at multiple scales: evidence for differential population responses in juvenile Chinook salmon. Journal of Animal Ecology, 75, 1100-1109.

Daufresne M, Roger MC, Capra H, Lamouroux N (2004) Long-term changes within the invertebrate and fish communities of the Upper Rhône River: effects of climatic factors. Global Change Biology, 10, 124-140.

Dudgeon D, Arthington AH, Gessner MO, Kawabata ZI, Knowler DJ, Leveque C, Naiman RJ, Prieur-Richard AH, Soto D, Stiassny MLJ, Sullivan CA (2006) Freshwater biodiversity: importance, threats, status and conservation challenges. Biological Reviews, 81, 163-182.

Durance I, Ormerod SJ (2007) Climate change effects on upland stream invertebrates over a 25 year period. Global Change Biology, 13, 942-957.

Durance I, Ormerod SJ (2009) Trends in water quality and discharge offset long-term warming effects on river macroinvertebrates. Freshwater Biology, 54, 388-455.

Eaton, JG, McCormick JH, Goodno BE, O'Brien DG, Stefany HG, Hondzo M, Scheller RM (1995) A field information-based system for estimating fish temperature tolerances. Fisheries, 20, 10-18.

Edwards RW, Brooker MP (1982) The ecology of the Wye. Dr. W. Junk Publishers, The Hague, Holland.

Elliott JM, Hurley MA (1995) The functional relationship between body size and growth rate in fish. Functional Ecology, 9, 625-627.

Elliott JM, Hurley MA (1997) A functional model for maximum growth of Atlantic salmon parr, Salmo salar, from two populations in northwest England. Functional Ecology, 11, 592- 603.

Elliott JM, Hurley MA, Elliott JA (1997) Variable effects of droughts on the density on a sea trout Salmo trutta population over 30 years. Journal of Applied Ecology, 34, 12291238 .

Elliott JM, Hurley MA, Maberly SC (2000) The emergence period of sea trout fry in a Lake District stream correlates with the North Atlantic Oscillation. Journal of Fish Biology, 56, 208-10.

Elliot SR, Coe TA, Helfield JM, Naiman, RJ (1998) Spatial variation in environmental characteristics of Atlantic salmon (Salmo salar) rivers. Canadian Journal of Fisheries and Aquatic Sciences, 55 Supplement 1, 267-280.

Environment Agency (1998) Local environment agency plan. Wye area. Environmental overview. Environment Agency, Cardiff, UK. 
Global Change Biology GCB-09-0020 revised

$\underline{609}$

$\underline{610}$

$\underline{611}$

$\underline{612}$

$\underline{613}$

614

$\underline{615}$

$\underline{616}$

$\underline{617}$

$\underline{618}$

$\underline{619}$

$\underline{620}$

$\underline{621}$

$\underline{622}$

$\underline{623}$

624

$\underline{625}$

$\underline{626}$

627

628

$\underline{629}$

$\underline{630}$

$\underline{631}$

$\underline{632}$

$\underline{633}$

$\underline{634}$

$\underline{635}$

$\underline{636}$

$\underline{637}$

$\underline{638}$

$\underline{639}$

$\underline{640}$

$\underline{641}$

$\underline{642}$

$\underline{643}$

644

$\underline{645}$

646

647

$\underline{648}$

649

650

651

652

$\underline{653}$

Environment Agency (2003a) Our nations' fisheries. The migratory and freshwater fisheries of England and Wales, Environment Agency., Bristol, UK.

Environment Agency (2003b) River Wye Salmon Action Plan. October 2003., Environment Agency, Bristol, UK.

Environment Agency and CEFAS (The Centre for Environment, Fisheries and Aquaculture Science) (2004) Annual assessment of salmon stocks and fisheries in England and Wales, 2003. Preliminary assessment prepared for ICES, March 2004., Environment Agency and CEFAS, Bristol, UK.

Flebbe PA, Roghair LD, Bruggink JL (2006) Spatial modeling to project southern Appalachian trout distribution in a warmer climate. Transactions of the American Fisheries Society, 135, 1371-1382.

Finney BP, Gregory-Eaves I, Sweetman J, Dougas MSV, Smol, JP (2000) Impacts of climatic change and fishing on Pacific salmon abundance over the past 300 years. Science, 290, 795-799.

Gee AS, Milner NJ (1980) Analysis of 70-year catch statistics for Atlantic salmon (Salmo salar) in the River Wye and implications for management of stocks. Journal of Applied Ecology, 17, 41-57.

Gee AS, Milner NJ, Hemsworth RJ (1978a) The production of juvenile Atlantic salmon, Salmo salar in the upper Wye, Wales. Journal of Fish Biology, 13, 439-451.

Gee AS, Milner NJ; Hemsworth RJ (1978b) Effect of density on mortality in juvenile Atlantic salmon (Salmo-salar). Journal of Animal Ecology, 47, 497-505

Gough, PG, Winstone, AJ, Hilder, PG (1992) A review of some factors affecting the abundance and catch of spring salmon from the River Wye and elsewhere and proposals for stock maintenance and enhancement., National Rivers Authority, Welsh region, Cardiff, UK.

Hakala JP, Hartman, KJ (2004) Drought effect on stream morphology and brook trout (Salvelinus fontinalis) populations in forested headwater streams. Hydrobiologia, 515, 203-213.

Hari, RE, Livingstone, DM, Siber, R, Burkhardt-Holm, P and Güttinger, H (2006) Consequences of climatic change for water temperature and brown trout populations in Alpine rivers and streams. Global Change Biology, 12, 10-26.

Hawkes HA (1975) River zonation and classification. In: Whitton, BA (Ed.) River ecology. Blackwell Scientific Publications, Oxford, pp. 312-74.

Hayes JW, Baird DB (1994) Estimating relative abundance of juvenile brown trout in rivers by underwater census and electrofishing. New Zealand Journal of Marine and Freshwater Research, 28, 243-253.

Hughes S, Morley, S (2000) Aspects of fisheries and water resources management in England and Wales. Fisheries Management and Ecology 7 75-84.

Hulme PE (2005) Adapting to climate change: is there scope for ecological management in the face of a global threat? Journal of Applied Ecology, 42, 784-794.

Hulme, M, Jenkins, GJ, Lu, X, Turnpenny, JR, Mitchell, TD, Jones, RG, Lowe, J, Murphy, JM, Hassell, D, Boorman, P, McDonald, R and Hill, S (2002) Climate change scenarios for the United Kingdom: the UKCIP02 Scientific report. April 2002., Tyndall Centre for Climate Change Research, School of Environmental Sciences, University of East Anglia, Norwich, UK. 
Global Change Biology GCB-09-0020 revised

$\underline{654}$

$\underline{655}$

$\underline{656}$

$\underline{657}$

$\underline{658}$

$\underline{659}$

$\underline{660}$

$\underline{661}$

$\underline{662}$

$\underline{663}$

$\underline{664}$

$\underline{665}$

$\underline{666}$

$\underline{667}$

$\underline{668}$

$\underline{669}$

$\underline{670}$

$\underline{671}$

$\underline{672}$

$\underline{673}$

$\underline{674}$

$\underline{675}$

$\underline{676}$

$\underline{677}$

$\underline{678}$

679

$\underline{680}$

$\underline{681}$

$\underline{682}$

$\underline{683}$

$\underline{684}$

$\underline{685}$

$\underline{686}$

$\underline{687}$

$\underline{688}$

$\underline{689}$

$\underline{690}$

$\underline{691}$

$\underline{692}$

$\underline{693}$

$\underline{694}$

$\underline{695}$

$\underline{696}$

$\underline{697}$

$\underline{698}$

Hurrell JW (1995) Decedal trends in the North Atlantic Oscillation: regional temperatures and precipitation. Science, 269, 676-679.

Jarvie HP, Neal C, Withers PJA, Robinson A, Salter, N (2003) Nutrient water quality of the Wye catchment, UK: exploring patterns and fluxes using the Environment Agency data archives. Hydrology and Earth System Sciences, 7, 722-743.

Jonsson B, Jonsson N (2004) Factors affecting marine production of Atlantic salmon (Salmo salar) Canadian Journal of Fisheries and Aquatic Sciences, 61, 2369-2383.

Juanes J, Letcher BH, Gries G (2000) Ecology of stream fish: insights gained from an individual-based approach to juvenile Atlantic salmon. Ecology of Freshwater Fish, 9 $65-73$.

Kennedy GJA, Crozier WW (1993) Juvenile Atlantic salmon - production and prediction. In: Gibson RJ, Cutting, RE (eds) Production of juvenile Atlantic salmon, Salmo salar, in natural waters. Canadian Special Publication of Fisheries Aquatic Sciences, 118, 179-187.

Lewis BR, Jüttner I, Reynolds B, Ormerod SJ (2007) Comparative assessment of stream acidity using diatoms and macroinvertebrates: implications for river management and conservation. Aquatic Conservation: Marine and Freshwater Ecosystems, 17, 502-519

Mackey AP, Berrie, AD (1991) The prediction of water temperatures in chalk sreams from air temperatures. Hydrobiologia, 210, 183-189

Marschall EA, Crowder, LB (1996) Assessing population responses to multiple anthropogenic effects: A case study with brook trout. Ecological Applications, 6, 152167.

Met Office (2004) Historic station data. Ross-On-Wye. [WWW] http://www. metoffice.com/climate/uk/stationdata/rossonwyedata.txt [Accessed : 8/2004]

McFarlane GA, King JR, Beamish RJ (2000) Have there been recent changes in climate? Ask the fish. Progress in Oceanography, 47, 147-169.

Milner NJ, Elliott JM, Armstrong JD, Gardiner R, Welton JS, Ladle M (2003) The natural control of salmon and trout populations in streams. Fisheries Research, 62, 111-125.

Moore A, Waring CP (2001) The effects of a synthetic pyrethroid pesticide on some aspects of reproduction in Atlantic salmon (Salmo salar L.). Aquatic Toxicology, 52, $1-12$.

NERC (Natural Environment Research Council) (2005) The national river flow archive. UK gauging station network. http://www.nerc-wallingford.ac.uk/ih/nrfa/station_ summaries [Accessed: 18/02/08].

Nislow KH, Einum S, Folt CL (2004) Testing predictions of the critical period for survival concept using experiments with stocked Atlantic salmon. Journal of Fish Biology, 65, 188-200.

Ormerod, SJ (1985) The distribution of aquatic macroinvertebrates in the catchment of the Welsh River Wye in relation to ionic composition. $\mathrm{PhD}$ thesis, University of Wales.

Ormerod SJ (2003) Current issues with fish and fisheries: editor's overview and introduction. Journal of Applied Ecology, 40, 204-213.

Ormerod SJ (2009) Climate change, river conservation and the adaptation challenge. Aquatic Conservation: Marine and Freshwater Ecosystems, 19, 609-613. 
Global Change Biology GCB-09-0020 revised

$\underline{699}$

$\underline{700}$

$\underline{701}$

$\underline{702}$

$\underline{703}$

704

$\underline{705}$

$\underline{706}$

$\underline{707}$

$\underline{708}$

709

$\underline{710}$

$\underline{711}$

$\underline{712}$

$\underline{713}$

714

$\underline{715}$

716

$\underline{717}$

$\underline{718}$

$\underline{719}$

$\underline{720}$

$\underline{721}$

$\underline{722}$

723

$\underline{724}$

$\underline{725}$

$\underline{726}$

727

728

$\underline{729}$

$\underline{730}$

$\underline{731}$

$\underline{732}$

$\underline{733}$

$\underline{734}$

$\underline{735}$

$\underline{736}$

$\underline{737}$

$\underline{738}$

$\underline{739}$

$\underline{740}$

$\underline{741}$

Ormerod SJ, Durance I (2009) Restoration and recovery from acidification in upland Welsh streams over 25 years. Journal of Applied Ecology, 46, 164-174.

Ormerod SJ, Edwards RW (1987) The ordination and classification of macroinvertebrate assemblages in the catchment of the River Wye in relation to environmental factors. Freshwater Biology, 17, 533-546.

Osborn $\mathrm{T}$ (2005) North Atlantic Oscillation index data. [WWW] http://www.cru.uea.ac.uk/ timo/projpages/nao_update.htm [Accessed: 18/8/2008].

Parrish DL, Behnke RJ, Gephard SR, McCormick SD, Reeves GH (1998) Why aren't there more Atlantic salmon (Salmo salar)? Canadian Journal of Fisheries and Aquatic Sciences, 55, 281-287.

Parsons LS, Lear WH (2001) Climate variability and marine ecosystem impacts: a North Atlantic perspective. Progress in Oceanography, 49, 167-188.

Pinheiro, JC. and Bates, DM. (2000) Mixed-Effects Models in S and S-PLUS. Springer, New-York.

Potter ECE, MacLean JC, Wyatt RJ, Campbell RNB (2003) Managing the exploitation of migratory salmonids. Fisheries Research, 62, 127-142.

Quinn GP, Keough MJ (2002) Experimental Design and Data Analysis for Biologists. Cambridge University Press, Cambridge, UK.

Quinn TP, McGinnity P, Cross TF (2006) Long-term declines in body size and shifts in run timing of Atlantic salmon in Ireland. Journal of Fish Biology, 68, 1713-1730.

R Development Core Team (2009). R: A language and environment for statistical computing. R Foundation for Statistical Computing, Vienna, Austria. ISBN

3-900051-07-0, URL http://www.R-project.org.

Regetz J (2003) Landscape-level constraints on recruitment of chinook salmon (Oncorhynchus tshawytscha) in the Columbia River basin, USA. Aquatic Conservation-Marine and Freshwater Ecosystems, 13, 35-49.

Reynolds JB (1996) Electrofishing, In: Fisheries techniques. 2nd edition (eds Murphy BR, Willis, DW) pp. 221-253 American Fisheries Society, Bethesda, Maryland.

Rieman B, Peterson JT, Clayton J, Howell P, Thurow R, Thompson W, Lee D (2001) Evaluation of potential effects of federal land management alternatives on trends of salmonids and their habitats in the interior Columbia River basin. Forest Ecology and Management, 153, 43-62.

Riley, W. D., Maxwell, D. L., Pawson, M. G. and Ives, M. J. 2009 The effects of low summer flow on wild salmon (Salmo salar), trout (Salmo trutta) and grayling (Thymallus thymallus) in a small stream. Freshwater Biology, 54, 2581-2599.

Roni P, Fayram A (2000) Estimating winter salmonid abundance in small western Washington streams: a comparison of three techniques. North American Journal of Fisheries Management, 20, 683-692.

Ruggerone GT, Nielsen JL, Bumgarner J (2007) Linkages between Alaskan sockeye salmon abundance, growth at sea, and climate, 1955-2002. Deep-Sea Research Part IiTopical Studies in Oceanography, 54, 2776-2793.

Rutherford JC, Marsh NA, Davies PM, Bunn SE (2004) Effects of patchy shade on stream water temperature: how quickly do small streams heat and cool? Marine and Freshwater Research, 55, 737-748. 
Global Change Biology GCB-09-0020 revised

SCA (Standing Committee of Analysts) (1978) The measurement of electrical conductivity and the laboratory determination of the $\mathrm{pH}$ value of natural, treated and waste waters. HMSO, London, UK.

SCA (Standing Committee of Analysts) (1979) Dissolved oxygen in natural and waste waters. HMSO, London, UK.

SCA (Standing Committee of Analysts) (1981) Ammonia in waters. HMSO, London, UK.

SCA (Standing Committee of Analysts) (1988) 5 day biochemical oxygen demand (BOD5) $2^{\text {nd }}$ Edition, HMSO, London, UK.

Seo H, Kim S, Seong K, Kang SY (2006) Variability in scale growth rates of chum salmon (Oncorhynchus keta) in relation to climate changes in the late 1980s. Progress in Oceanography, 68, 205-216

SPSS for Windows (2001) SPSS. Base System. SPSS Inc., Chicago.

Slaney TL, Hyatt KD, Northcote TG, Fielden RJ (1996) American Fisheries Society North Pacific International Chapter. Status of Anadromous Salmon and Trout in British Columbia and Yukon. Fisheries, 21, 20-35.

Strange CD, Aprahamian MW, Winstone AJ (1989) The assessment of a semiquantitative sampling technique for juvenile Atlantic salmon and trout in small streams. Aquaculture and Fisheries Management, 21, 47-66.

Suttle KB, Power ME, Levine JM., McNeely C (2004) How fine sediment in riverbeds impairs growth and survival of juvenile salmonids. Ecological Applications, 14, 969974.

Tabachnick BG, Fidell LS (2001) Using multivariate statistics. Allyn and Bacon, London.

Taylor SG (2008) Climate warming causes phenological shift in Pink Salmon, Oncorhynchus gorbuscha, behavior at Auke Creek, Alaska. Global Change Biology, 14, 229-235.

Todd CD, Hughes SL, Marshall CT, Maclean JC, Lonergan ME, Biuw EM (2008) Detrimental effects of recent ocean surface warming on growth condition of Atlantic salmon. Global Change Biology, 14, 958-970.

Twisk JWR (2006) Applied Multilevel Analysis. A practical guide. Cambridge University Press, Cambridge, UK.

Van Der Leeden, R. (1998) Multilevel Analysis of Repeated Measures Data. Quality \& Quantity 32, 15-29.

Walsh CL, Kilsby CG (2007) Implications of climate change on flow regime affecting Atlantic salmon. Hydrology and Earth System Sciences, 11, 1125-1141.

Watanabe M, Adams RM, Wu JJ, Bolte JP, Cox MM, Johnson SL, Liss WJ, Boggess WG, Ebersole JL (2005) Toward efficient riparian restoration: integrating economic, physical, and biological models. Journal of Environmental Managemen, t 75, 93-104.

Webb BW, Clack PD, Walling DE (2003) Water-air temperature relationships in a Devon river system and the role of flow. Hydrological Processes, 17, 3069-3084

Wilzbach MA, Mather ME, Folt CL, Moore A, Naiman RJ, Youngson AF, McMenemy J (1998) Proactive responses to human impacts that balance development and Atlantic salmon conservation (Salmo salar): an integrative model. Canadian Journal of Fisheries and Aquatic Sciences, 55, 288-302. 
Global Change Biology GCB-09-0020 revised

$\underline{788}$ Wood SN (2006) Generalized Additive Models: An Introduction with $R$. Chapman and $\underline{789}$ Hall/CRC. Boca Raton, Florida, USA.

$\underline{790}$ Zabel RW, Scheuerell MD, McClure MM, Williams JG (2006) The interplay between $\underline{791}$ climate variability and density dependence in the population viability of Chinook $\underline{792}$ salmon. Conservation Biology, 20, 190-200. 
Global Change Biology GCB-09-0020 revised

796 Table 1: Generalised regression relationships $(y=a+b x)$ between weekly mean stream 797 temperature at sites in the catchment of the Welsh River Wye and air temperature at 798 Newbridge-on Wye (After Ormerod 1985). Regressions are shown respectively for $\underline{799}$ lower-order headwaters with riparian shading and larger-order main channels with less $\underline{800}$ riparian vegetation.

$\begin{array}{llll}\mathrm{a} \pm 95 \% \mathrm{CI} \quad \mathrm{b} \pm 95 \% \mathrm{CI} & \mathrm{N} & 100 . \mathrm{r}^{2}\end{array}$

Headwaters

$3.40 \pm 0.40$

$0.715 \pm 0.039$

159

89.1

Main channels

$3.07 \pm 0.77$

$0.942 \pm 0.075$

77

89.3 
Page 33 of 45

Global Change Biology

$$
\begin{array}{ll}
1 & \\
2 & \\
3 & \\
4 & \underline{801} \\
5 & \underline{802} \\
6 & \underline{803} \\
7 & \underline{804} \\
8 & \\
9 & \\
10 & \\
11 & \\
12 & \\
13 & \\
14 & \\
15 & \underline{805} \\
16 & \underline{806} \\
17 &
\end{array}
$$

18

19

20

21

22

23

24

25

26

27

28

29

30

31

32

33

34

35

36

37

38

39

40

41

42

43

44

45

46

47

48

49

50

51

52

53

54

55

56

57

58

59

60

$\frac{\frac{807}{808}}{\underline{809}}$
Global Change Biology GCB-09-0020 revised

Table 2. Multilevel regression models of log transformed juvenile density of a) salmon and b) trout against year in the River Wye catchment detailing regression coefficients (Estimate $\pm \mathrm{SE}$ ), 95\% confidence intervals (CI) and corresponding $\rho$-values.

a) Salmon

\begin{tabular}{lrrrr} 
Variable & Estimate $(\mathrm{SE})$ & $\mathrm{t}$ & $\rho$ & \multicolumn{1}{c}{$95 \% \mathrm{CI}$} \\
\hline & & & & \\
Intercept & $34.08(4.83)$ & 7.06 & $<0.001$ & $24.31-43.84$ \\
Year & $-0.02(0.002)$ & -6.93 & $<0.001$ & $-0.02--0.01$ \\
\hline
\end{tabular}

b) Trout

\begin{tabular}{lcrcc} 
Variable & Estimate $(\mathrm{SE})$ & $\mathrm{t}$ & $\rho$ & $95 \% \mathrm{CI}$ \\
\hline & & & & \\
Intercept & $28.59(5.4)$ & 5.30 & $<0.001$ & $17.67-39.50$ \\
Year & $-0.01(0.003)$ & -5.16 & $<0.001$ & $-0.02--0.01$ \\
\hline
\end{tabular}

32 
Global Change Biology GCB-09-0020 revised

$\underline{810}$ Table 3. Principal Component (PC) axes representing variation in 'climatic variables' $\underline{811}$ and 'water quality' relevant to the Wye system recorded between 1985 and 2000 in $\underline{812}$ summer (April - September) and winter (October - March), respectively. Eigenvectors $\underline{813}$ indicate the loading of variables on the first PC axis extracted in Principal Component $\underline{814}$ Analyses.

Summer 'climate' component

$48.9 \%$ variance explained

Sun hours

Discharge $\mathrm{m}^{3} / \mathrm{s}$

Rain $\mathrm{mm}$

$\operatorname{Tmin}{ }^{\circ} \mathrm{C}$

$\operatorname{Tmax}{ }^{\circ} \mathrm{C}$

NAO index

Winter 'climate' component

$45.0 \%$ variance explained

Sun hours

Discharge $\mathrm{m}^{3} / \mathrm{s}$

Rain mm

$\operatorname{Tmin}{ }^{\circ} \mathrm{C}$

$\operatorname{Tmax}{ }^{\circ} \mathrm{C}$

NAO index
Summer 'water quality' component

$40.3 \%$ variance explained

0.907 Ammonia N mg/l

0.722

0.762

-0.856 BOD mg/l

$\begin{array}{rlr}-0.851 & \text { Dissolved Oxygen mg/l } & -0.639 \\ 0.081 & \mathrm{pH} & 0.317\end{array}$

0.755

0.278

$\underline{815}$

Winter 'water quality' component

$47.3 \%$ variance explained

0.278 Ammonia N mg/l $\quad 0.739$

0.702 BOD mg/l 0.606

0.619 Dissolved Oxygen mg/l $\quad-0.696$

$0.857 \mathrm{pH}$

0.704

0.885

0.479 
Global Change Biology GCB-09-0020 revised

$\underline{816}$

$\underline{817}$

$\underline{818}$

$\underline{819}$

$\underline{820}$

$\underline{821}$

$\underline{822}$

$\underline{823}$

$\underline{824}$

b)

\begin{tabular}{lrrrr} 
Variable & Estimate (SE) & \multicolumn{1}{c}{$\mathrm{t}$} & \multicolumn{1}{c}{$\rho$} & \multicolumn{1}{c}{$95 \%$ CI } \\
\hline & & & & \\
Intercept & $0.67(0.04)$ & 16.85 & $<0.001$ & $0.59-0.74$ \\
Summer 'climate' last year & $-0.04(0.01)$ & -2.98 & 0.003 & $-0.06--0.01$ \\
Winter 'climate' last year & $-0.01(0.01)$ & -0.45 & 0.654 & $-0.03-0.02$ \\
Summer 'water quality' last year & $-0.03(0.02)$ & -1.34 & 0.180 & $-0.07-0.01$ \\
Winter 'water quality' last year & $-0.02(0.02)$ & -0.68 & 0.500 & $-0.06-0.03$ \\
\hline
\end{tabular}

Table 4. Multilevel regression models of environmental factors on log transformed juvenile density in a) salmon and b) trout in the River Wye catchment detailing regression coefficients (Estimate $\pm \mathrm{SE}$ ), 95\% confidence intervals $(\mathrm{CI})$ and corresponding $\rho$-values.

a)

13 
Global Change Biology GCB-09-0020 revised

$\underline{828}$ Table 5. Values of raw climatic variables (monthly average) at 5, 25, 75 and 95 $\underline{829}$ percentiles of Principal Component scores derived from a Principal Component Analysis $\underline{830}$ of summer climatic variables relevant to the Wye river system (see Table 3 for loadings).

$\underline{831}$

\begin{tabular}{llllllll}
\hline Percentiles & $\begin{array}{l}\text { PC1summer } \\
\text { scores }\end{array}$ & $\begin{array}{l}\text { Rainfall } \\
(\mathrm{mm})\end{array}$ & $\begin{array}{l}\text { Sun } \\
\text { (hours) }\end{array}$ & NAO & $\begin{array}{l}\text { Discharge } \\
\left(\mathrm{m}^{3} / \mathrm{s}\right)\end{array}$ & $\begin{array}{l}\text { Tmax } \\
{ }^{\circ} \mathrm{C}\end{array}$ & $\begin{array}{l}\text { Tmin } \\
{ }^{\circ} \mathrm{C}\end{array}$ \\
\hline $5 \%$ & -1.469 & 62.4 & 173.3 & -0.131 & 0.346 & 18.2 & 9.3 \\
$25 \%$ & -0.828 & 48.2 & 169.8 & -0.588 & 0.264 & 18.6 & 10.1 \\
$75 \%$ & 0.761 & 38.2 & 202.1 & -0.222 & 0.130 & 18.9 & 9.0 \\
$95 \%$ & 1.762 & 36.0 & 213.6 & 0.340 & 0.124 & 20.5 & 10.0 \\
\hline
\end{tabular}

$\underline{832}$ 
Global Change Biology GCB-09-0020 revised

$\underline{834}$

$\underline{835}$ Table 6. Slopes relating monthly mean or median stream to air temperature in a range of

$\underline{836}$ lowland chalk-fed streams and Welsh rivers and streams (1: Durance and Ormerod 2009;

$\underline{837}$ 2: Mackey and Berrie 1991; 3: Durance and Ormerod 2007; 4: Crisp 1997; 5: this study)

$\underline{838}$

Site

$b \pm \mathrm{SE}$

\section{Chalk streams}

Itchen, Eastleigh $^{1}$ (SU 454157)

Bere, Dorset ${ }^{1}$ (SY 859 919)

Avon, Amesbury ${ }^{1}$ (SU 151413 )

$0.76 \pm 0.01$

$0.68 \pm 0.02$

$0.51 \pm 0.02$

Frome $^{2}$ (SY868861)

Lambourne $^{2}$ (SU452693)

$0.94 \pm 0.02$

Winterbourne $^{2}$ (SU453694)

$0.62 \pm 0.02$

Tadnol Brook ${ }^{2}$ (SY800874)

$0.48 \pm 0.02$

$0.74 \pm 0.03$

\section{Welsh rivers and streams}

Moorland stream (CI6; SN772 556) ${ }^{3}$

$0.94 \pm 0.04$

Moorland/forest stream (AT; SN804 538) ${ }^{3}$

$0.97 \pm 0.04$

Forest stream (LI1; SN809 529) ${ }^{3}$

$0.78 \pm 0.09$

Plynlimon forest stream (Hafren; SN8487) ${ }^{4}$

$0.66-0.73$

Plynlimon forest steram (Hore; SN8388) ${ }^{4}$

0.51-0.71

Wye catchment, wooded headwaters ${ }^{5}$

$0.72 \pm 0.04$

Wye catchment, main tributaries 5

$0.94 \pm 0.07$ 
Global Change Biology GCB-09-0020 revised

$\underline{842} \quad$ Figure Legends

$\underline{843}$

$\underline{844}$ Figure 1. Location of electrofishing sites within the catchment of the Welsh River Wye $\underline{845}$ (small symbols), showing also those with chemical data (larger symbols).

$\underline{846}$

Figure 2. Standardised (mean $\mathrm{z}$ scores $\pm \mathrm{SE}$ ) relative densities of juvenile $(>0+)$ salmon and trout juveniles averaged across tributaries of the Welsh River Wye, 1985 - 2004. N indicates the number of rivers contributing to mean annual density in each year.

Figure 3. Long-term trends the annual (a: $y=0.0413 x-70.759 \bullet ; y=0.0314 x-52.637$

$\left.\circ ; r^{2}=0.38\right)$, summer (b; $y=0.0339 x-50.414 \bullet ; y=0.0257 x-37.194 \circ ; r^{2}=0.1164$ ) and winter $\left(\mathrm{c} ; y=0.0504 x-93.782 \bullet ; y=0.0383 x-70.113 \circ ; r^{2}=0.1411\right)$ temperature of tributaries of the River Wye as estimated from trends in air temperature using generalised calibrations respectively from three larger, unshaded tributaries $(\bullet)$ and five shaded headwaters $(0)$. Panel d) shows trends in residual winter temperature after accounting for the significant of the NAO (see text) $(y=0.0732 x-145.95 \bullet ; y=0.0556 x$ $\underline{858}-110.78 \circ ; r 2=0.4264)$.

859

Figure 4. Long-term variations in discharge during summer (a) and winter (b) at the CEH Hafren Flume, Plynlimon.

Figure 5. Densities of $>0+$ salmon (a) and brown trout (b) per $100 \mathrm{~m}^{2}$ reach averaged (mean \pm SE) across tributaries of the Wye catchment in each year plotted against an index $\underline{865}$ on antecedent summer climate. This is derived as the first component from a Principal $\underline{866}$ Components Analysis (PC) on climatic variables during the (see Table 3). 
Global Change Biology GCB-09-0020 revised

870 Appendix 1. Frequency of sampling of salmonids in the Wye catchment 1985-2004. $\underline{871}$ Years which included quantitative sampling of rivers are indicated by *. Monitoring was $\underline{872}$ not undertaken in 1996. Rivers which were split into upstream and downstream reaches $\underline{873}$ according to proximity, geology and stream order are indicated by upstream ' $\mathrm{u} / \mathrm{s}$ ' and $\underline{874}$ downstream 'd/s', respectively. 
Global Change Biology GCB-09-0020 revised

Year

\begin{tabular}{|c|c|c|c|c|c|c|c|c|c|c|c|c|c|c|c|c|c|c|}
\hline \multirow[b]{2}{*}{ River } & \multicolumn{18}{|c|}{ Year } \\
\hline & $\stackrel{\curvearrowleft}{2}$ & $\stackrel{\circ}{\curvearrowright}$ & $\stackrel{\curvearrowright}{\curvearrowright}$ & $\begin{array}{l}\infty \\
\propto \\
\approx\end{array}$ & $\stackrel{2}{\stackrel{一}{二}}$ & ڤু & $\bar{\sigma}$ & گ̆ & $\hat{\sigma}$ & ğ & 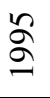 & $\hat{\sigma}$ & $\stackrel{\infty}{2}$ & ळे & 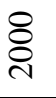 & ॄิ & ڤి & ¿্ণ \\
\hline Aran & $2 *$ & 2 & 1 & 1 & 1 & 1 & 1 & 1 & 1 & 1 & 1 & 3 & 0 & 3 & 0 & $1^{*}$ & $3 *$ & $1 *$ \\
\hline Arrow (d/s) & 2 & 2 & $1^{*}$ & 1 & 0 & 0 & 0 & 0 & 0 & 0 & 0 & 1 & $4^{*}$ & 1 & 0 & $1^{*}$ & $2^{*}$ & $1 *$ \\
\hline Arrow (u/s) & 4 & 4 & $3 *$ & 3 & $4^{*}$ & $4^{*}$ & $4^{*}$ & $3^{*}$ & $4^{*}$ & $3^{*}$ & 3 & 6 & $2 *$ & 6 & 0 & $2^{*}$ & $6^{*}$ & $2 *$ \\
\hline Bidno & 2 & 2 & 2 & 2 & 2 & 2 & 2 & 2 & $8 *$ & 2 & 1 & $2 *$ & $1 *$ & $2^{*}$ & $1^{*}$ & $1^{*}$ & $5^{*}$ & $1 *$ \\
\hline Bleddfa & 0 & 0 & 0 & 0 & 0 & 0 & 0 & 1 & 1 & 1 & 1 & 1 & 0 & 1 & 0 & $0^{*}$ & $2^{*}$ & $0 *$ \\
\hline Cammarch & 1 & 1 & 0 & 0 & 1 & 1 & 2 & 2 & 2 & 2 & 2 & 3 & 0 & 3 & 0 & 1 & 4 & 1 \\
\hline Chwerfri & $3 *$ & $2 *$ & $2 *$ & $2 *$ & 2 & 4 & 1 & $1^{*}$ & $17^{*}$ & 1 & 2 & 3 & 0 & 2 & 0 & $1^{*}$ & $9 *$ & $1 *$ \\
\hline Cledan & 2 & 1 & 1 & 1 & 1 & 1 & 1 & 1 & 1 & 1 & 1 & 1 & 0 & 1 & 0 & 0 & 2 & 0 \\
\hline Clettwr & 0 & 0 & 0 & 0 & 0 & 0 & 0 & 0 & 0 & 0 & 0 & 4 & 3 & 3 & 0 & 0 & 2 & 0 \\
\hline Clywedog & $3 *$ & $2 *$ & $2 *$ & $2 *$ & $2^{*}$ & $2^{*}$ & $2^{*}$ & $1^{*}$ & $1 *$ & $2^{*}$ & 2 & $6^{*}$ & $3 *$ & $2^{*}$ & $1^{*}$ & $1^{*}$ & $5^{*}$ & $1 *$ \\
\hline Cnyffiad & 2 & 1 & 1 & 1 & 1 & 1 & 1 & 1 & $14 *$ & 1 & 1 & 3 & 3 & 0 & 0 & 0 & 2 & 1 \\
\hline Dernol & $2 *$ & $2 *$ & $1 *$ & $1 *$ & $1^{*}$ & $1^{*}$ & $1^{*}$ & 1 & $9^{*}$ & $1^{*}$ & 1 & $1 *$ & $1^{*}$ & $1^{*}$ & $1 *$ & $1^{*}$ & $3^{*}$ & $1 *$ \\
\hline Dore & 3 & 6 & $3 *$ & $3 *$ & $3^{*}$ & 3 & $3^{*}$ & $5^{*}$ & $3^{*}$ & $1^{*}$ & 2 & 4 & $6^{*}$ & 4 & 0 & 0 & 1 & 0 \\
\hline Duhonw & $2^{*}$ & $2 *$ & $1^{*}$ & $1^{*}$ & $1^{*}$ & $1^{*}$ & $2^{*}$ & $3^{*}$ & $2^{*}$ & $2^{*}$ & 1 & $5^{*}$ & $6^{*}$ & $1^{*}$ & $1^{*}$ & 0 & $6^{*}$ & $1 *$ \\
\hline Dulas (Ithon) & 2 & 2 & 1 & 1 & 0 & 1 & 1 & 0 & $11^{*}$ & 0 & 1 & $2 *$ & 0 & 2 & $1^{*}$ & $1^{*}$ & 2 & $1 *$ \\
\hline Dulas brook & 0 & 0 & 0 & 0 & 0 & 0 & 0 & 0 & 0 & 0 & 0 & $3^{*}$ & $3 *$ & 0 & 0 & 0 & 2 & 0 \\
\hline Edw & $4 *$ & $3^{*}$ & $2^{*}$ & $2 *$ & $2^{*}$ & $2 *$ & $2^{*}$ & $2 *$ & $2 *$ & $2^{*}$ & 2 & $2^{*}$ & $1^{*}$ & $2 *$ & $1^{*}$ & $1^{*}$ & $4^{*}$ & $1 *$ \\
\hline Einon & 1 & 1 & 0 & 0 & 0 & 0 & 0 & 1 & 1 & 1 & 1 & 1 & 0 & 1 & 0 & $1^{*}$ & $1 *$ & $1 *$ \\
\hline Frome & 0 & 0 & 0 & 0 & 1 & 1 & 3 & 5 & 3 & 0 & 3 & 5 & 0 & 6 & 0 & 0 & 2 & 0 \\
\hline Garth Dulas & 3 & $3 *$ & $2^{*}$ & $2^{*}$ & $2^{*}$ & $2^{*}$ & $1^{*}$ & $2^{*}$ & $2^{*}$ & $2^{*}$ & 2 & $4^{*}$ & $8^{*}$ & $7 *$ & 0 & $1^{*}$ & $5^{*}$ & $1 *$ \\
\hline Gwesyn & 1 & 1 & 1 & 0 & 1 & 1 & 1 & 1 & 1 & 1 & 1 & 1 & 0 & 2 & 0 & 0 & 1 & 0 \\
\hline Hafrena & 0 & 0 & 0 & 0 & 0 & 0 & 0 & 0 & 0 & 0 & 0 & $3 *$ & 3 & 0 & 0 & 0 & 1 & 0 \\
\hline Hindwell & 2 & 2 & $1^{*}$ & $1 *$ & $2^{*}$ & $2^{*}$ & $2^{*}$ & 0 & $2 *$ & $1^{*}$ & 2 & $9 *$ & 9 & 0 & 0 & $1^{*}$ & $1 *$ & $1^{*}$ \\
\hline Honddu & 3 & 7 & $4^{*}$ & $4 *$ & $4 *$ & $4 *$ & $4^{*}$ & $3^{*}$ & $3^{*}$ & $3^{*}$ & 3 & 4 & 0 & 4 & 0 & 0 & 2 & 0 \\
\hline Irfon & $5^{*}$ & $5^{*}$ & $4^{*}$ & 3 & $4 *$ & 4 & 2 & 2 & $12 *$ & 2 & 2 & 1 & 0 & 6 & 0 & $2^{*}$ & $4^{*}$ & $1^{*}$ \\
\hline Ithon & $5^{*}$ & $4^{*}$ & $2^{*}$ & $2 *$ & $2^{*}$ & $2^{*}$ & $2^{*}$ & $2^{*}$ & $2 *$ & 1 & 3 & $6^{*}$ & $1 *$ & $4 *$ & $1^{*}$ & $2^{*}$ & $4^{*}$ & $2 *$ \\
\hline Lingen Brook & 1 & 1 & 1 & 1 & 1 & 1 & 1 & 1 & 1 & 1 & 1 & 1 & 0 & 1 & 0 & 0 & 2 & 0 \\
\hline $\begin{array}{l}\text { Llanwrthwl } \\
\text { Brook }\end{array}$ & $2 *$ & $1^{*}$ & $1^{*}$ & $1^{*}$ & $1^{*}$ & $1^{*}$ & $1^{*}$ & 1 & $10^{*}$ & $1^{*}$ & 0 & $1^{*}$ & $1 *$ & $1^{*}$ & $1^{*}$ & $1^{*}$ & $1^{*}$ & $1^{*}$ \\
\hline Llynfi & $4 *$ & $3 *$ & $2^{*}$ & $2^{*}$ & $2^{*}$ & $2^{*}$ & $2^{*}$ & $4^{*}$ & 2 & 0 & 2 & 3 & 0 & 3 & 0 & $2^{*}$ & $5^{*}$ & $1^{*}$ \\
\hline Llynfi dulas & 2 & 1 & 0 & 0 & 0 & 0 & 0 & 0 & 0 & 0 & 0 & 4 & 2 & 2 & 0 & 0 & 4 & 0 \\
\hline Lodon & 0 & 0 & 0 & 0 & 0 & 0 & 2 & 3 & 2 & 0 & 2 & 2 & 0 & 1 & 0 & $1^{*}$ & $4^{*}$ & $1^{*}$ \\
\hline $\operatorname{Lugg}(\mathrm{d} / \mathrm{s})$ & 1 & 1 & $1^{*}$ & 1 & 0 & 1 & 0 & 8 & 0 & 1 & 1 & 2 & $11^{*}$ & 2 & 0 & 0 & 0 & $4^{*}$ \\
\hline $\operatorname{Lugg}(\mathrm{u} / \mathrm{s})$ & 6 & 5 & $2 *$ & $2 *$ & $5^{*}$ & $3 *$ & $3 *$ & $4^{*}$ & $4 *$ & $4^{*}$ & 4 & 5 & 0 & 5 & 0 & $2^{*}$ & $7 *$ & $2^{*}$ \\
\hline Marteg & $4^{*}$ & $3 *$ & $2^{*}$ & $2 *$ & 2 & 2 & 2 & 2 & $17^{*}$ & 2 & 2 & $3 *$ & $1^{*}$ & $3 *$ & $1^{*}$ & $2^{*}$ & $8^{*}$ & $2^{*}$ \\
\hline Monnow & 3 & 7 & $3^{*}$ & $3 *$ & $3 *$ & $3 *$ & $3 *$ & $2^{*}$ & $3 *$ & $2^{*}$ & 2 & 4 & $5^{*}$ & 4 & $3^{*}$ & $4^{*}$ & $9^{*}$ & 0 \\
\hline Nant Gwynfel & 0 & 0 & 0 & 0 & 0 & 0 & 1 & 1 & 0 & 1 & 1 & 1 & 1 & 1 & 0 & 0 & 1 & 0 \\
\hline Norton Brook & 1 & 1 & 1 & 1 & 0 & 0 & 1 & 1 & 1 & 1 & 0 & 1 & 0 & 1 & 0 & 0 & 2 & 0 \\
\hline Olchon & 1 & 3 & 0 & 1 & 1 & 1 & 1 & 1 & 1 & 0 & 1 & 1 & 0 & 1 & $4^{*}$ & $4^{*}$ & $8^{*}$ & 0 \\
\hline Pinsley Brook & 2 & 2 & 1 & 0 & 1 & 1 & 1 & $1^{*}$ & 1 & 1 & 0 & 1 & 0 & 4 & 0 & $2^{*}$ & $4^{*}$ & $2 *$ \\
\hline Sgithwen & $2^{*}$ & $2 *$ & $1^{*}$ & $1^{*}$ & 1 & 1 & 0 & 0 & 0 & 0 & 0 & $6^{*}$ & 6 & 6 & 0 & $2^{*}$ & $4^{*}$ & $1 *$ \\
\hline South Dulas & $4^{*}$ & $2 *$ & $2^{*}$ & $2^{*}$ & $1^{*}$ & $1^{*}$ & $2^{*}$ & 1 & $2^{*}$ & $2^{*}$ & 2 & $2 *$ & $1^{*}$ & $2^{*}$ & $1 *$ & $1^{*}$ & $3^{*}$ & $2 *$ \\
\hline Triffrwyd & 2 & 1 & 1 & 1 & 1 & 1 & 1 & 1 & 1 & 0 & 1 & 1 & 0 & 1 & 0 & 0 & 2 & 0 \\
\hline Trothy & 3 & 5 & 2 & 2 & 2 & 2 & 2 & 1 & 4 & 0 & 2 & 4 & 0 & 3 & 0 & 0 & 0 & 0 \\
\hline
\end{tabular}


Global Change Biology GCB-09-0020 revised

$\underline{876}$ Figure 1

$\underline{878}$

$\underline{879}$

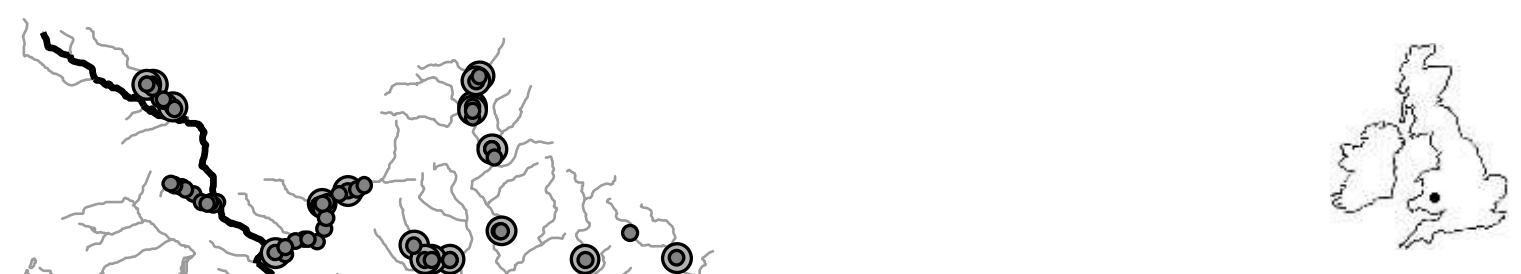


Global Change Biology GCB-09-0020 revised

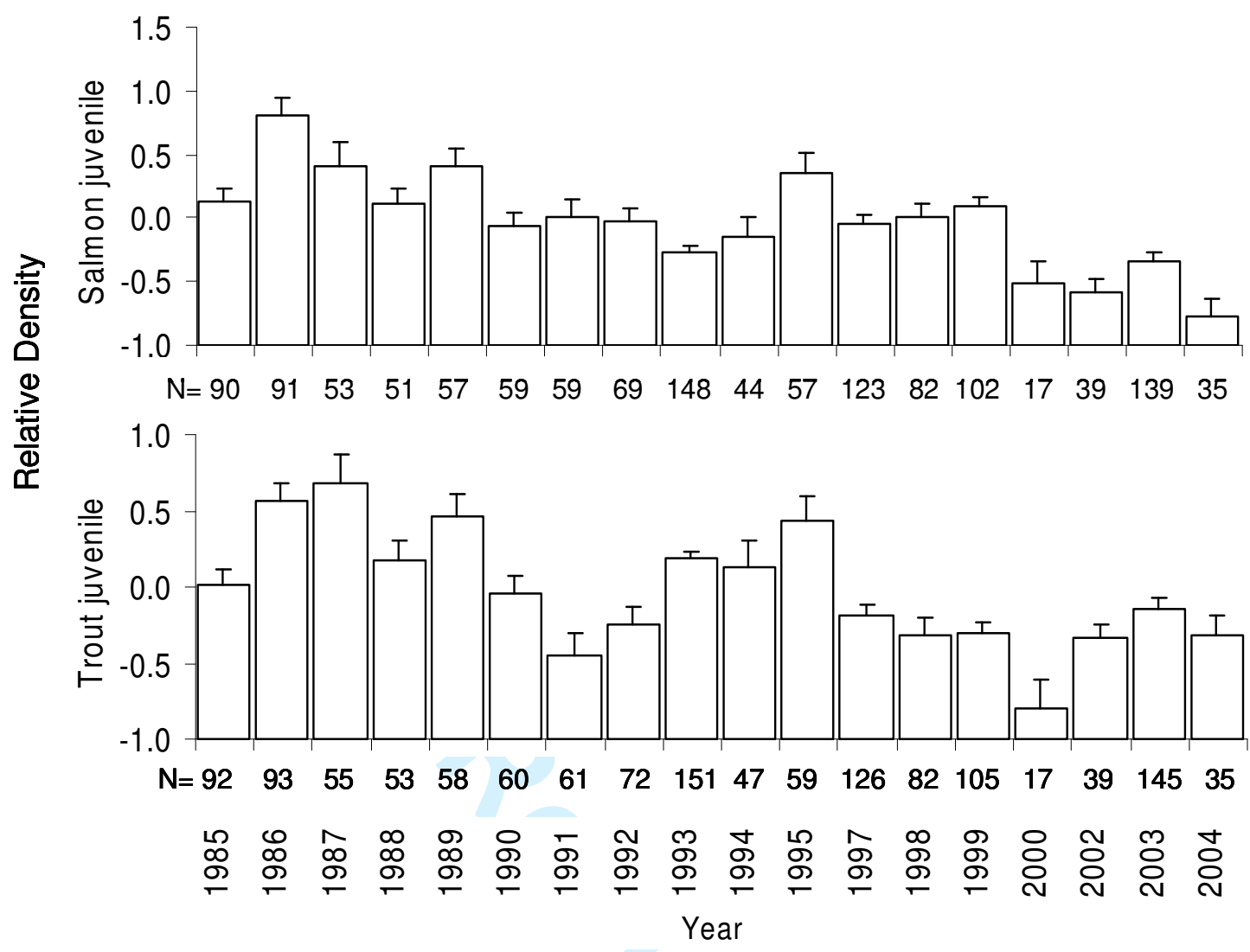

$\underline{880}$ Year

$\underline{881}$

$\underline{882}$ Figure 2

$\underline{883}$ 


\section{Page 43 of 45}

Global Change Biology GCB-09-0020 revised

\section{Figure 3:}




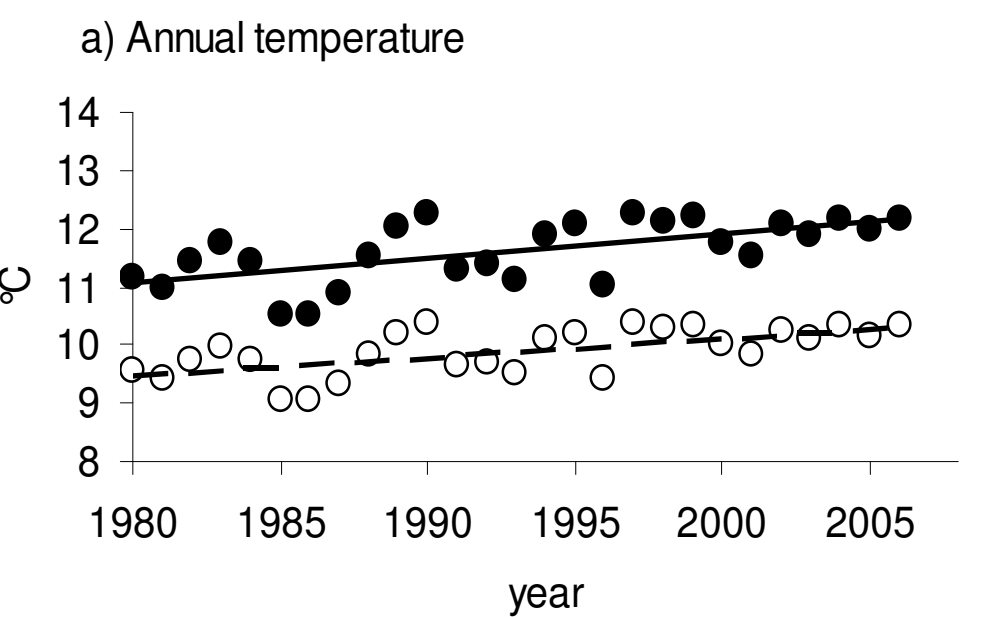

c) Winter temperature

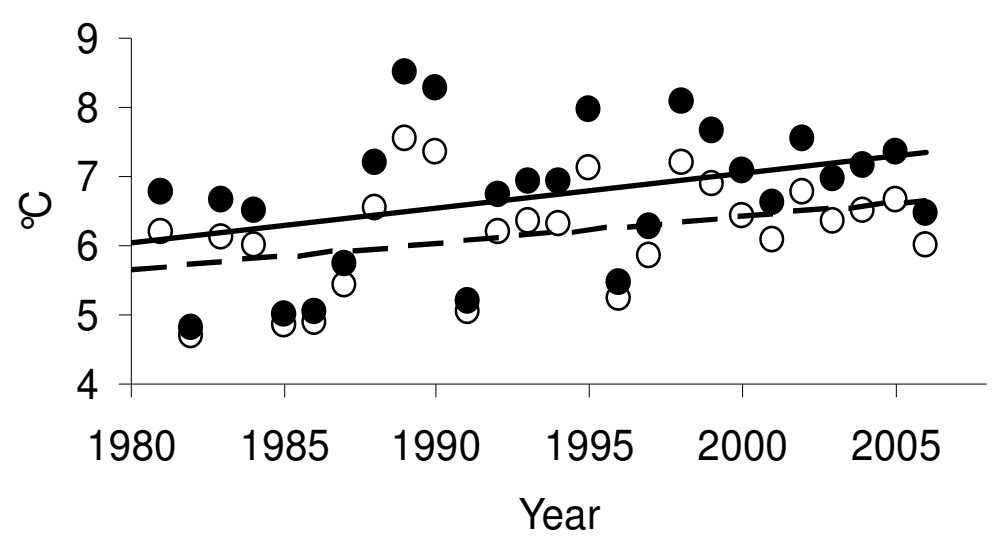

b) Summer temperature

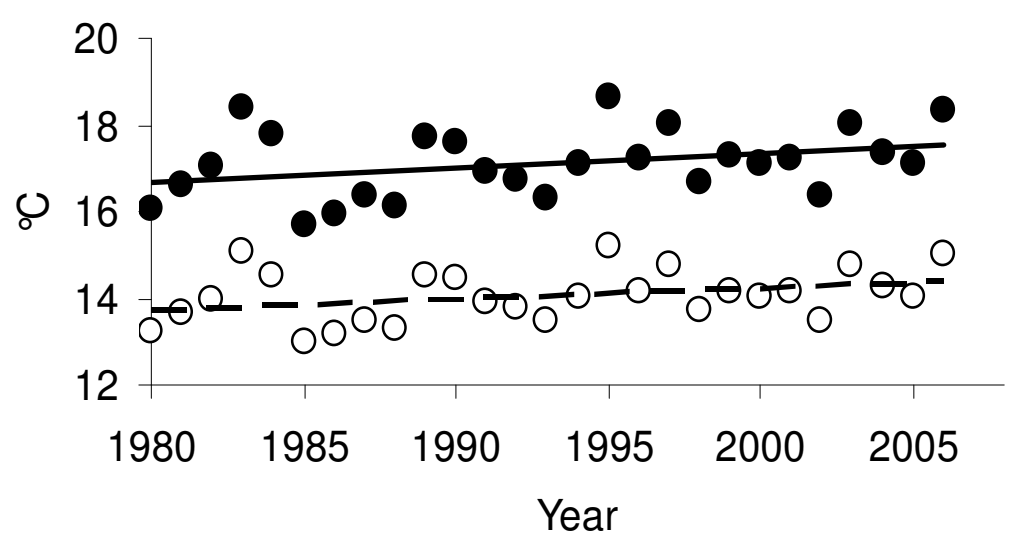

d) Winter temperature residual after NAO

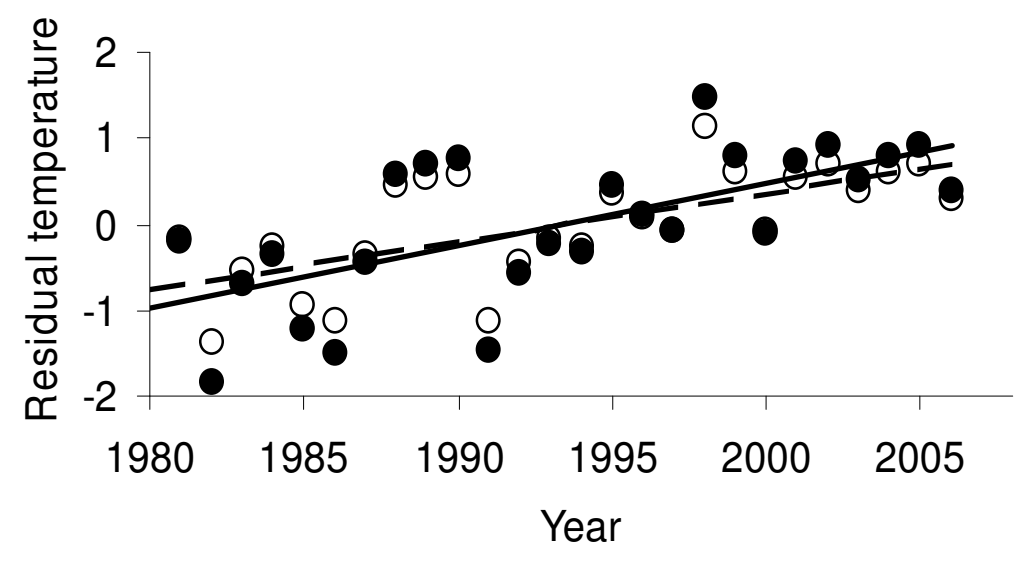




\section{Figure 4}
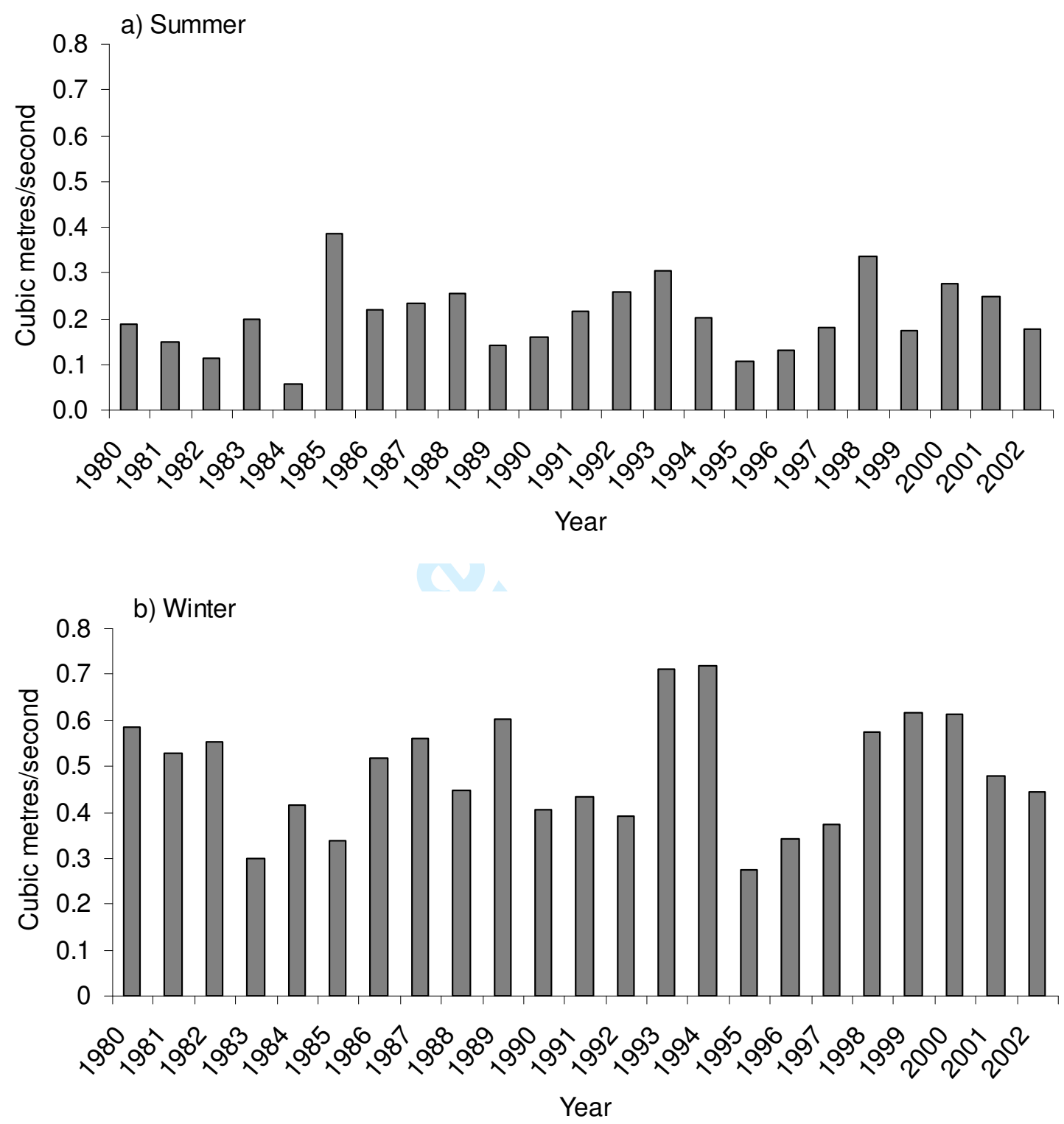


\section{Figure 5}
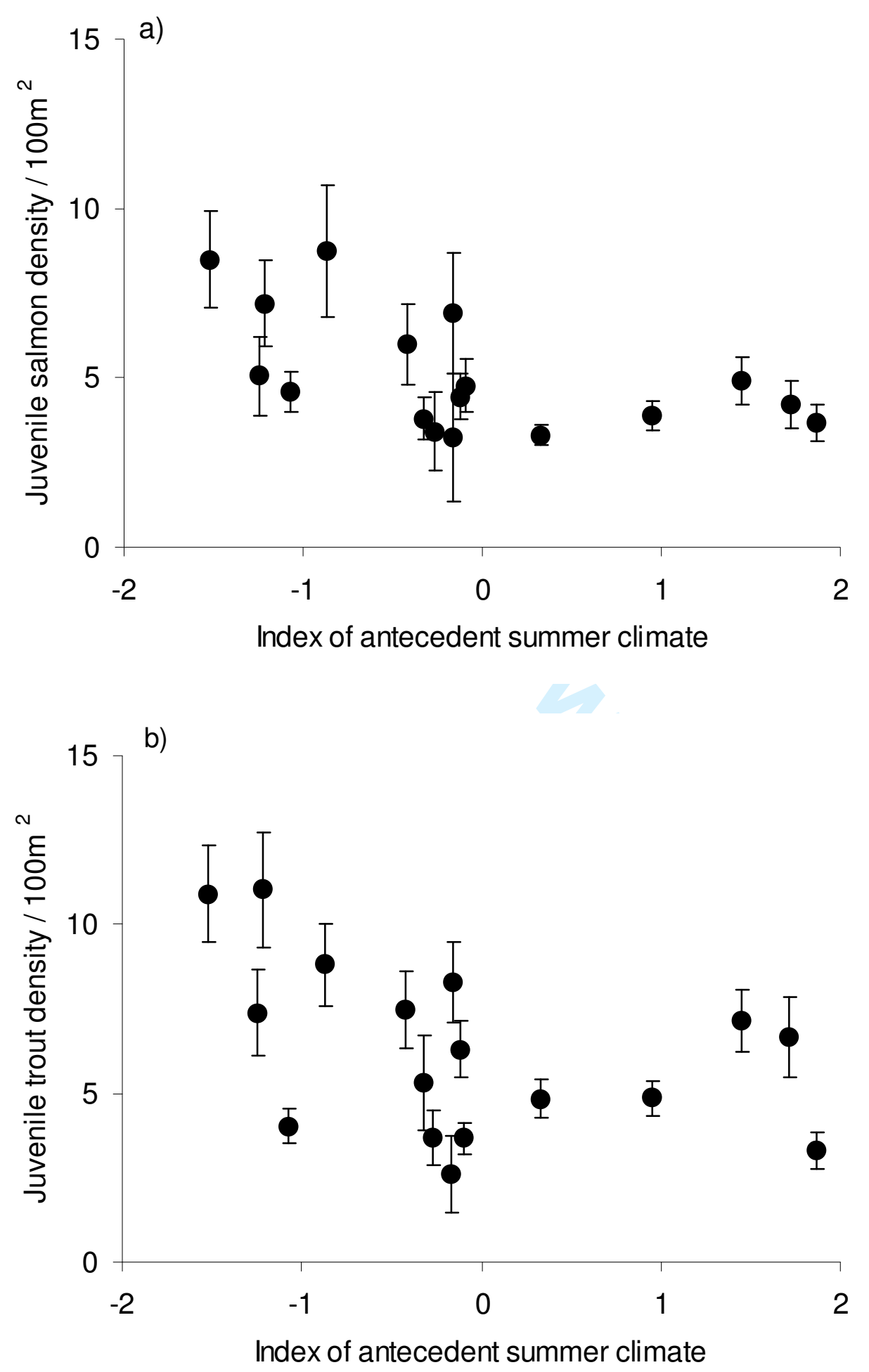